Article

\title{
Structural Insights into New Bi(III) Coordination Polymers with Pyridine-2,3-Dicarboxylic Acid: Photoluminescence Properties and Anti-Helicobacter pylori Activity
}

\author{
Mateusz Kowalik 1,*(D), Joanna Masternak ${ }^{1}\left(\mathbb{D}\right.$, Iwona Lakomska ${ }^{2, * \mathbb{D}}$, \\ Katarzyna Kazimierczuk ${ }^{3}$ (D), Anna Zawilak-Pawlik ${ }^{4}$ (D), Piotr Szczepanowski ${ }^{4}$, \\ Oleksiy V. Khavryuchenko ${ }^{5}$ and Barbara Barszcz ${ }^{1}$ \\ 1 Institute of Chemistry, Jan Kochanowski University in Kielce, Uniwersytecka 7, 25-406 Kielce, Poland; \\ joanna.masternak@ujk.edu.pl (J.M.); barbara.barszcz@ujk.edu.pl (B.B.) \\ 2 Faculty of Chemistry, Nicolaus Copernicus University in Toruń, Gagarina 7, 87-100 Toruń, Poland \\ 3 Department of Inorganic Chemistry, Faculty of Chemistry, Gdańsk University of Technology, \\ G. Narutowicza 11/12, 80-233 Gdańsk, Poland; katarzyna.kazimierczuk@pg.gda.pl \\ 4 Laboratory of Molecular Biology of Microorganisms, Microbiology Department, \\ Hirszfeld Institute of Immunology and Experimental Therapy, Polish Academy of Sciences, \\ Weigla 12, 53-114 Wrocław, Poland; anna.pawlik@hirszfeld.pl (A.Z.-P.); \\ szczepanowski.piotr@gmail.com (P.S.) \\ 5 Shupyk National Medical Academy of Postgraduate Education (NMAPE), \\ Dorogozhytska 9, 04112 Kyiv, Ukraine; alexkhavr@gmail.com \\ * Correspondence: mateuszkowalik.86@gmail.com (M.K.); iwolak@chem.umk.pl (I.Ł.); \\ Tel.: +48-56-611-4510 (I.Ł.)
}

Received: 15 October 2020; Accepted: 17 November 2020; Published: 18 November 2020

check for updates

\begin{abstract}
Two novel coordination polymers, $\left[\mathrm{Bi}_{2}(2,3 p y d c)_{2}(2,3 p y d c H)_{2}\left(\mathrm{H}_{2} \mathrm{O}\right)\right]_{\mathrm{n}}(\mathbf{1})$ and $\left\{\left(\mathrm{Et}_{3} \mathrm{NH}\right)_{2}\right.$ $\left[\mathrm{Bi}(2,3 \mathrm{pydc})(2,3\right.$ pydcH $\left.\left.) \mathrm{Cl}_{2}\right]\right\}_{\mathrm{n}}$ (2) were prepared using as a prolinker pyridine-2,3-dicarboxylic acid $\left(2,3\right.$ pydc $\left.\mathrm{H}_{2}\right)$. The obtained complexes were fully characterized by elemental analysis, TG/DTG, FT-IR, solid-state photoluminescence, DFT calculations and single-crystal X-ray diffraction. The obtained complexes crystallized in the triclinic $P-1$ space group (1) and comprise dimeric units with two crystallographically different $\mathrm{Bi}(\mathrm{III})$ centers (polyhedra: distorted pentagonal bipyramid and bicapped trigonal prism) and monoclinic $P 2_{1} / c$ space group (2) with a distorted monocapped pentagonal bipyramid of $\mathrm{Bi}(\mathrm{III})$ center. The various coordination modes of bridging carboxylate ligands are responsible for the formation of $1 \mathrm{D}$ chains with 4,5C10 (1) and $2 \mathrm{C} 1$ (2) topology. The photoluminescence quantum yield for polymer $\mathbf{2}$ is $8.36 \%$, which makes it a good candidate for more specific studies towards Bi-based fluorescent materials. Moreover, it was detected that polymer $\mathbf{1}$ is more than twice as active against H. pylori as polymer 2. It can be concluded that there is an existing relationship between the structure and the antibacterial activity because the presence of chloride and triethylammonium ions in the structure of complex 2 reduces the antibacterial activity.
\end{abstract}

Keywords: Bi(III) coordination polymers; pyridine-2,3-dicarboxylic acid; holodirected and hemidirected geometry; photoluminescence; Helicobacter pylori

\section{Introduction}

Contemporary coordination chemistry establishes a scientific basis for obtaining compounds used as sources for synthesizing functional materials not only for technology [1-7] but also for medicine or pharmacy $[8,9]$. It is a great challenge to obtain proper functional materials because the properties of 
coordination compounds depend on the type of both metal ions and connecting ligands. Our interest in this field concerns the chemistry of lead(II) [10-14] and bismuth(III) coordination polymers with heteroaromatic carboxylate ligands. When selecting a central ion, we focused on the multiple applications of Bi(III) compounds as, for example, photoluminescent materials [15-17], catalysts [18], medical drugs for gastrointestinal disorders caused by Helicobacter pylori or anticancer agents [19-22]. Furthermore, the $\mathrm{Bi}(\mathrm{III})$ ion exhibits a $[\mathrm{Xe}] 4 f^{14} 5 d^{10} 6 s^{2}$ ground state electronic configuration and belongs to a group of metal ions (Tl(I), $\mathrm{Pb}(\mathrm{II}), \mathrm{Sn}(\mathrm{II}), \mathrm{Sb}(\mathrm{III}))$ possessing a lone electron pair $\left(\mathrm{ns}^{2}\right)$. The presence of a lone electron pair, its stereochemical role and a relatively large bismuth covalent radius (1.48 $\AA$ [23]) can lead to the formation of interesting molecular structures of Bi-based complexes, including high coordination numbers and a hemi- or holodirected distribution of ligands around the metal center. When the lone electron pair is stereochemically inactive, it does not affect the geometry of the metal coordination environment. The bonds between metal and ligands are distributed symmetrically and the geometry around the central ion is defined as holodirected. While when the electron pair is stereochemically active, it occurs in a separate place in the central ion environment. The coordination bonds are distributed asymmetrically and only in a certain part of the coordination sphere. Such a type of geometry is called hemidirected [24]. These features make Bi(III) a coordinatively flexible ion, which is why we chose it for the synthesis of novel bismuth(III) coordination polymers. Additionally, the varied coordination structures of bismuth(III) complexes are also affected by the kind of donating ligand and the different coordination modes. This is especially important in the synthesis of functional coordination polymers (CPs), where ligands play an additional role as organic linkers. Among these linkers, carboxylate ligands are special, mainly due to the large variation in their coordination behavior. They can act as (i) monodentate $\mathrm{\kappa O}$, (ii) chelating $\kappa^{2} \mathrm{O}, \mathrm{O}^{\prime}$, (iii) bridging $\mu-\mathrm{kO}: \mathrm{KO}^{\prime}, \mu-\mathrm{kO}: \mathrm{kO}, \mu_{3}-\mathrm{kO}: \mathrm{KO}^{\prime}: \mathrm{kO}^{\prime}, \mu_{4}-\mathrm{kO}: \mathrm{kO}: \mathrm{KO}^{\prime}: \mathrm{KO}^{\prime}$ and (iv) chelating-bridging $\mu-\kappa^{2} \mathrm{O}_{1} \mathrm{O}^{\prime}: \mathrm{KO}^{\prime}$, $\mu_{3}-\kappa \mathrm{O}: \kappa^{2} \mathrm{O}, \mathrm{O}^{\prime}: \mathrm{KO}^{\prime}, \mu_{4}-\mathrm{kO}: \kappa^{2} \mathrm{O}, \mathrm{O}^{\prime}: \mathrm{KO}^{\prime}: \mathrm{kO}^{\prime}, \mu_{5}-\mathrm{\kappa O}: \kappa \mathrm{K}: \kappa^{2} \mathrm{O}, \mathrm{O}^{\prime}: \mathrm{kO}^{\prime}: \kappa \mathrm{O}^{\prime}$ ligands [25]. When researching examples of functional bismuth(III) coordination polymers in the literature, we focused on complexes with isomeric pyridine-dicarboxylic acids as linkers: pyridine-2,3-dicarboxylic acid $\left(2,3 \mathrm{pydcH}_{2}\right)$ [26], pyridine-2,5-dicarboxylic acid $\left(2,5 \mathrm{pydcH}_{2}\right)$ [27-31], pyridine-2,6-dicarboxylic acid $\left(2,6 \mathrm{pydcH}_{2}\right)$ [32-37], pyridine-3,4-dicarboxylic acid $\left(3,4\right.$ pydcH $\left._{2}\right)$ [37] and pyridine-3,5-dicarboxylic acid $\left(3,5 \mathrm{pydcH}_{2}\right)$ [38]. A literature search of coordination polymer functionality revealed six examples of $\mathrm{Bi}(\mathrm{III})$ complexes with luminescence properties [27,28,31,32,38]; three compounds exhibited gas-sorption behavior $\left(\mathrm{CO}_{2}, \mathrm{~N}_{2}, \mathrm{H}_{2}\right)$ [32], and one was used as a precursor for the preparation of $\mathrm{Bi}_{2} \mathrm{O}_{3}$ nanoparticles via thermal decomposition [26]. However, the biological activity of the mentioned complexes have not been examined, although all of the bismuth compounds clinically used against Helicobacter pylori belong to a group of Bi(III) carboxylates (bismuth subsalicylate (BSS, Pepto-Bismol), colloidal bismuth subcitrate (CBS, De-Nol) or ranitidine bismuth citrate (RBC, Pylorid)) [39,40]. Currently, the problems associated with this microaerophilic and neutralophilic Gram negative bacterium have been intensively investigated because it has been linked not only to many gastrointestinal disorders but also to gastric cancer. It should be noted that bismuth medications have been used not only against H. pylori as a component of quadruple therapies [41] as the first-line treatment (two antibiotics, proton-pump inhibitor and Bi-based drug), but Bi(III) complexes have also demonstrated anticancer activity. Additionally, bismuth was employed in radiation therapy in the form of Bi-nanoparticles and nanodots or in targeted radioimmunotherapy in the form of bismuth radionuclides [42]. Considering all of the above aspects of interesting bismuth chemistry, herein, we present the synthesis and characterization of new $\mathrm{Bi}(\mathrm{III})$ metal-organic coordination polymers. Taking into consideration our previous experience in the construction of $\mathrm{CPs}$ based on $\mathrm{Pb}$ (II) ions [10-14], we paid special attention to the choice of a proper organic linker. We selected pyridine-2,3-dicarboxylic acid as the prolinker for this purpose. It belongs to the group of multidonating N,O-donor ligands, which can exist in a mono- or a fully deprotonated form, indicating the possibility of different coordination modes with metal ions [43-55] (Scheme 1). 


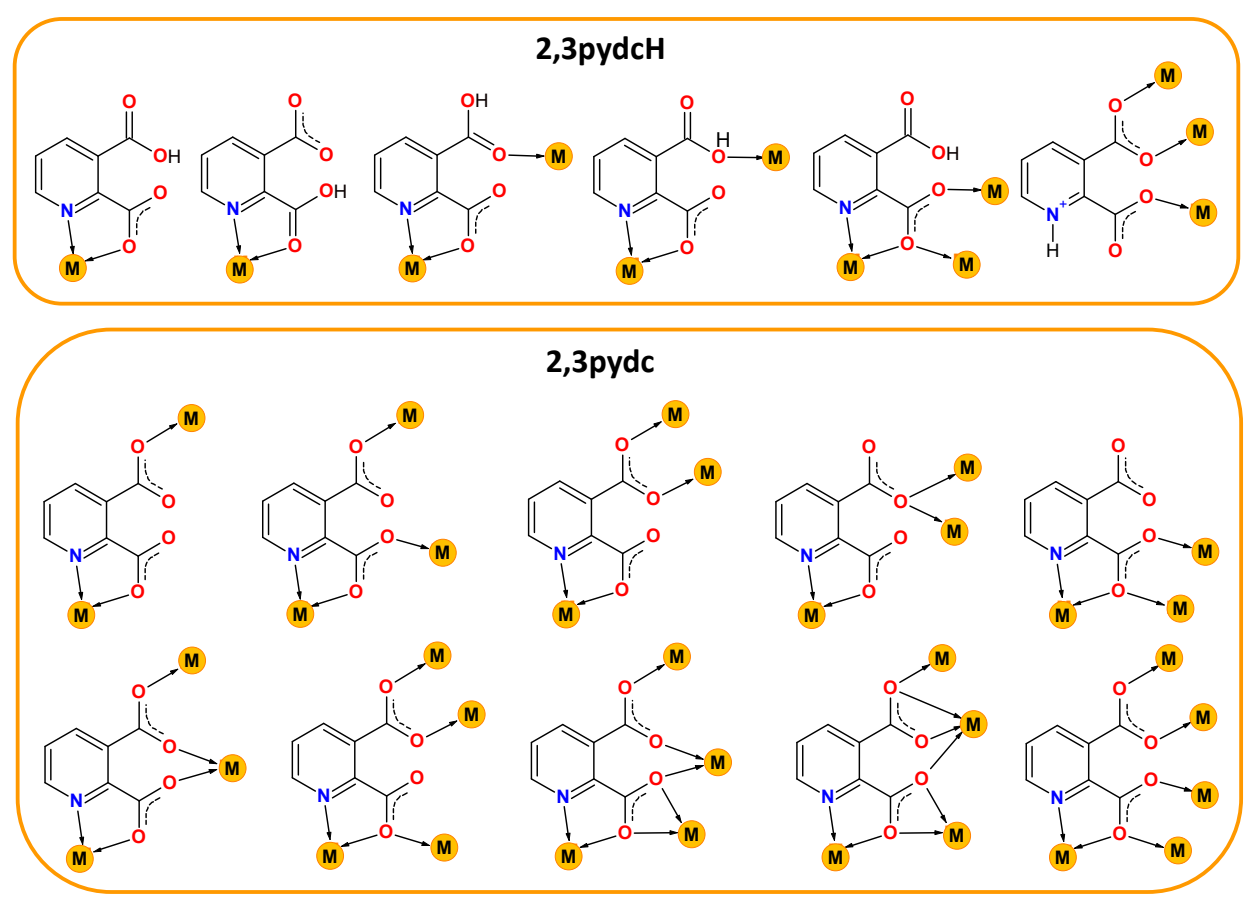

Scheme 1. Selected coordination modes of mono-deprotonated-2,3pydcH (top) and deprotonated2,3pydc (bottom) forms of pyridine-2,3-dicarboxylic acid $\left(2,3 \mathrm{pydcH}_{2}\right)$ in coordination with different metal ions reported in the literature [43-55].

During the course of this study, we (i) synthesized and fully physicochemically characterized two novel bismuth(III) coordination polymers with pyridine-2,3-dicarboxylic acid $\left(2,3 \mathrm{pydcH}_{2}\right)$ as a prolinker; (ii) presented the molecular structure and topology of $\left[\mathrm{Bi}_{2}(2,3 p y d c)_{2}(2,3 p y d c H)_{2}\left(\mathrm{H}_{2} \mathrm{O}\right)\right]_{\mathrm{n}}$ (1) and $\left\{\left(\mathrm{Et}_{3} \mathrm{NH}\right)_{2}\left[\mathrm{Bi}\left(2,3 \text { pydc) }(2,3 \text { pydcH }) \mathrm{Cl}_{2}\right]\right\}_{\mathrm{n}}\right.$ (2); (iii) confirmed and visualized the intermolecular close contacts in the crystal structures; (iv) carried out DFT (density functional theory) calculations to provide an explanation for the lone pair activity; (v) studied the luminescence properties of the obtained coordination polymers in the solid-state; and (vi) determined the bacteriostatic activity against H. pylori, which was compared with other Bi(III) carboxylate complexes.

\section{Results and Discussion}

\subsection{Molecular Structure and Lone Pair Stereoactivity}

The SC-XRD studies revealed that the coordination polymer $\left[\mathrm{Bi}_{2}(2,3 p y d c)_{2}(2,3 p y d c H)_{2}\left(\mathrm{H}_{2} \mathrm{O}\right)\right]_{n}$ (1) crystallized in the triclinic space group $P-1$. The asymmetric unit contained dimeric units of two crystallographically distinguishable Bi(III) centers. There were two anions of pyridine-2,3-dicarboxylic acid for each Bi center, one deprotonated (2,3pydc) and one mono-deprotonated (2,3pydcH). Additionally, there was one water molecule coordinated to the Bi1 center (Figure 1a). Each metal center existed in a different coordination environment. Around the Bi1 atom, there was a structural gap between the N2, O7 and O15 donor atoms, suggesting the influence of the lone electron pair on the geometry of the coordination sphere. The coordination bonds with those atoms were significantly longer (2.521-2.710 $\AA$ ) than those with the other atoms (O5, O1 and N1, 2.314-2.386 $)$ ) and were located opposite to the location of the lone electron pair (Table 1). Taking into consideration only the mentioned strong bonds, the geometry of the nearest coordination environment of the Bi1 center exhibited a coordination number of 7 and could be described as hemidirected. However, due to the significant stereoactivity of the lone electron pair, there were two additional donor atoms (O8 and O17) which were more distant from the Bi1 center (2.829 and $2.841 \AA$, respectively). These atoms, connected 
by weaker secondary bonds, completed the Bi1 coordination sphere. Therefore, the coordination number increased to 9, and the Bi1 coordination environment resembled a holodirected geometry [24]. The difference between the longest and shortest coordination bonds was $0.527 \AA$, which indicated a significant distortion of the coordination polyhedron. The Bi2 center was surrounded by eight donor atoms connected by strong primary bonds (2.311-2.650 $\mathrm{A}$ ) and one atom (O16) connected at a distance of $2.842 \AA$ (secondary bond). In this case, the geometry of the Bi2 center was determined as hemidirected for $\mathrm{CN}=8$ or holodirected for $\mathrm{CN}=9$ [24].

It is important to confirm the conclusions drawn from the crystallographic analysis by DFT calculations. One of the crucial factors affecting the lone electron pair stereoactivity is the type of orbital, i.e., a spherical $s$ orbital or space-oriented $p$ or $d$ orbitals, in which the electron density is mainly localized. Concerning compound 1, the stereoactivity of the lone electron pair was slightly more pronounced in the Bi1 center than in Bi2 (Figure 1b). The localization of the lone electron pair in the Bi1 center indicated a significant contribution of the $p$ orbital $(35.3 \%)$ and a smaller contribution of the $s$ orbital (9.5\%). This caused the electron density to occupy a hemisphere in close proximity to the metal center. As a result, there was a gap in the structure, and the surrounding Bi1 atom adopted a hemidirected geometry. The lone pair stereoactivity in the Bi1 center caused the distortion of the coordination environment but simultaneously allowed for the formation of two additional coordination bonds with atoms located at a distance $>2.8 \AA$. Therefore, the coordination geometry was not a typical hemidirected geometry since including secondary bonds filled up the hemisphere, resulting in a holodirected geometry. In turn, there was a smaller contribution of the $p$ orbital $(30.2 \%)$ and a slightly greater contribution of the $s$ orbital (12.0\%) in the localization of the electron pair in the Bi2 center than in the Bi1 center. As a result, the electron density in the Bi2 center affected the distortion of the coordination environment to a lower extent, and there was only one atom connected with the metal center by a secondary bond. However, concerning only primary bonds, the geometry of Bi2 was hemidirected, while including secondary bonds resulted in a holodirected geometry.

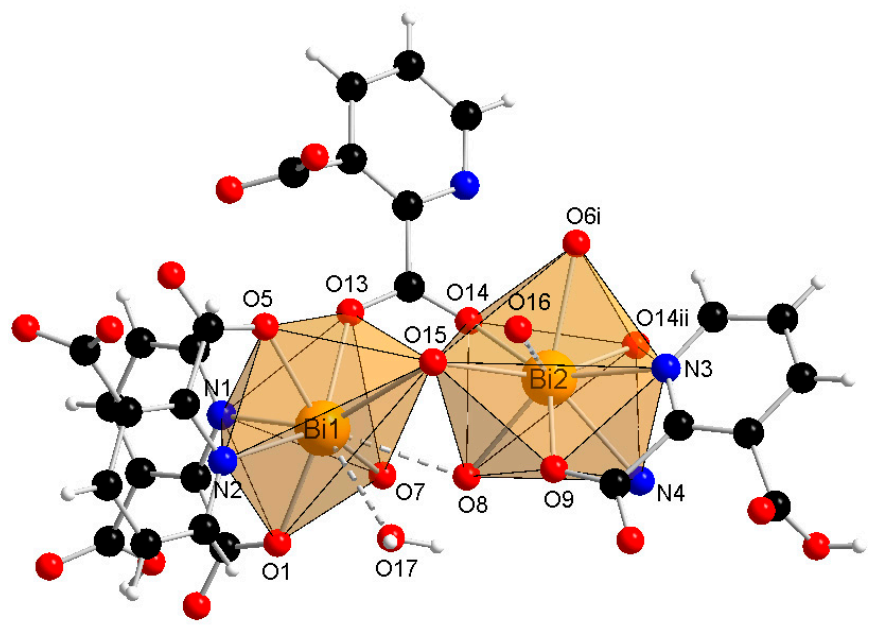

(a)


(b)

Figure 1. (a) The molecular structure with an atom numbering scheme of complex $\mathbf{1}$ (Symmetry codes: (i) - x, 1-y, 1-z; (ii) 1-x, 1-y, 1-z) (Bi-orange, O-red, N-blue, C-black, H-white); (b) graphical representation of selected molecular orbital localized on Bi atom in complex $\mathbf{1}$ (DFT calculations). 
Table 1. Selected bond lengths $(\AA)$ and angles $\left(^{\circ}\right)$ for complex 1.

\begin{tabular}{|c|c|c|c|c|c|c|c|}
\hline \multicolumn{8}{|c|}{ Bond Lengths (Å) } \\
\hline Bi1-O5 & $2.314(10)$ & Bi1-O7 & $2.697(9)$ & Bi2-O9 & $2.311(9)$ & $\mathrm{Bi} 2-\mathrm{O} 14^{\mathrm{ii}}$ & $2.539(9)$ \\
\hline Bi1-O1 & $2.332(9)$ & Bi1-O15 & $2.710(9)$ & Bi2-O15 & $2.433(9)$ & $\mathrm{Bi} 2-\mathrm{N} 4$ & $2.640(11)$ \\
\hline Bi1-N1 & $2.386(12)$ & Bi1-O8 & $2.829(10)$ & Bi2-O8 & $2.484(10)$ & Bi2-O14 & $2.650(10)$ \\
\hline Bi1-O13 & $2.443(9)$ & Bi1-O17 & $2.841(10)$ & $\mathrm{Bi} 2-\mathrm{O}^{\mathrm{i}}$ & $2.491(9)$ & Bi2-O16 & $2.842(10)$ \\
\hline Bi1-N2 & $2.521(12)$ & & & Bi2-N3 & $2.506(10)$ & & \\
\hline \multicolumn{8}{|c|}{ Bond Angles ( $\left.{ }^{\circ}\right)$} \\
\hline O1-Bi1-N2 & 74.3(4) & O5- & $-\mathrm{O} 7$ & 141.6(3) & \multicolumn{2}{|c|}{ O15-Bi2-N3 } & $117.4(4)$ \\
\hline O1-Bi1-N1 & $68.8(4)$ & O5-1 & -O17 & $121.4(3)$ & \multicolumn{2}{|c|}{ O15-Bi2-N4 } & $141.6(3)$ \\
\hline O1-Bi1-O5 & $131.9(3)$ & $\mathrm{O} 13$ & $-\mathrm{O} 15$ & $72.8(3)$ & \multicolumn{2}{|c|}{ O15-Bi2-O9 } & $77.2(3)$ \\
\hline O1-Bi1-O13 & $135.0(3)$ & O13- & $1-\mathrm{O} 8$ & $88.2(3)$ & \multicolumn{2}{|c|}{ O14-Bi2-O16 } & 117.2(3) \\
\hline O1-Bi1-O15 & $143.0(3)$ & O13- & $1-\mathrm{O} 7$ & $77.9(3)$ & \multicolumn{2}{|c|}{$\mathrm{O} 14-\mathrm{Bi} 2-\mathrm{O}^{\mathrm{i}}$} & $70.4(3)$ \\
\hline O1-Bi1-O8 & $88.8(3)$ & $\mathrm{O} 13$ & -O17 & $140.9(3)$ & \multicolumn{2}{|c|}{ O14-Bi2-O14 ii } & $71.6(3)$ \\
\hline O1-Bi1-O7 & 67.3(3) & $\mathrm{O} 15$ & $1-\mathrm{O} 8$ & $65.0(3)$ & \multicolumn{2}{|c|}{ O14-Bi2-N3 } & 145.4(3) \\
\hline O1-Bi1-O17 & $71.9(3)$ & O15- & $1-\mathrm{O} 7$ & $106.3(3)$ & \multicolumn{2}{|c|}{ O14-Bi2-N4 } & 111.2(3) \\
\hline N2-Bi1-N1 & $84.0(4)$ & O15- & $1-017$ & $72.6(3)$ & \multicolumn{2}{|c|}{ O14-Bi2-O9 } & $144.6(3)$ \\
\hline N2-Bi1-O5 & 66.1(3) & O8- & $1-\mathrm{O} 7$ & $47.9(3)$ & \multicolumn{2}{|c|}{ O16-Bi2-O6 ${ }^{\mathrm{i}}$} & $79.4(3)$ \\
\hline N2-Bi1-O13 & $130.9(3)$ & O8-1 & -O17 & $60.9(3)$ & \multicolumn{2}{|c|}{ O16-Bi2-O14 ${ }^{\mathrm{ii}}$} & $138.5(3)$ \\
\hline N2-Bi1-O15 & $107.2(3)$ & O7-1 & -O17 & $95.0(3)$ & \multicolumn{2}{|c|}{ O16-Bi2-N3 } & $69.3(4)$ \\
\hline N2-Bi1-O8 & $137.8(3)$ & O8-1 & -O15 & $74.5(3)$ & \multicolumn{2}{|c|}{ O16-Bi2-N4 } & 131.2(3) \\
\hline N2-Bi1-O7 & $141.2(3)$ & O8-1 & -O14 & $72.2(3)$ & \multicolumn{2}{|c|}{ O16-Bi2-O9 } & $65.1(3)$ \\
\hline N2-Bi1-O17 & $77.1(4)$ & O8-1 & -O16 & 115.1(3) & \multicolumn{2}{|c|}{$\mathrm{O} 6^{\mathrm{i}-\mathrm{Bi} 2-\mathrm{O} 14^{\mathrm{ii}}}$} & $65.4(3)$ \\
\hline N1-Bi1-O5 & $80.6(4)$ & O8-1 & $-6^{\mathrm{i}}$ & $142.4(3)$ & \multicolumn{2}{|c|}{ O6 ${ }^{\mathrm{i}-\mathrm{Bi} 2-\mathrm{N} 4}$} & 78.3(4) \\
\hline N1-Bi1-O13 & $77.0(4)$ & O8-B & $\mathrm{O} 14^{\mathrm{ii}}$ & 106.2(3) & \multicolumn{2}{|c|}{$\mathrm{O} 6^{\mathrm{i}-\mathrm{Bi} 2-\mathrm{N} 4}$} & $122.8(3)$ \\
\hline N1-Bi1-O15 & 147.6(3) & O8- & $2-N 3$ & $138.0(6)$ & \multicolumn{2}{|c|}{ O6 ${ }^{\mathrm{i}-\mathrm{Bi} 2-O 9}$} & $138.6(3)$ \\
\hline N1-Bi1-O8 & $126.0(4)$ & O8- & $2-N 4$ & $75.4(3)$ & \multicolumn{2}{|c|}{$\mathrm{O} 14^{\mathrm{ii}-\mathrm{Bi} 2-\mathrm{N} 3}$} & $82.5(5)$ \\
\hline N1-Bi1-O7 & $78.1(4)$ & O8- & $2-09$ & 75.5(3) & \multicolumn{2}{|c|}{$\mathrm{O} 14^{\mathrm{ii}-\mathrm{Bi} 2-\mathrm{N} 4}$} & $61.7(3)$ \\
\hline N1-Bi1-O17 & $139.7(4)$ & O15- & 2-O14 & $80.7(3)$ & \multicolumn{2}{|c|}{ O14 ${ }^{\mathrm{ii}-\mathrm{Bi} 2-\mathrm{O} 9}$} & $132.0(3)$ \\
\hline O5-Bi1-O13 & $66.4(3)$ & O15- & $2-\mathrm{O} 16$ & $48.6(3)$ & \multicolumn{2}{|c|}{ N3-Bi2-N4 } & $73.3(6)$ \\
\hline O5-Bi1-O15 & $76.8(3)$ & O15- & $2-06^{i}$ & $95.5(3)$ & \multicolumn{2}{|c|}{ N3-Bi2-O9 } & $69.2(6)$ \\
\hline O5-Bi1-O8 & 139.1(3) & O15-E & -O14 ii & $150.7(3)$ & \multicolumn{2}{|c|}{ N4-Bi2-O9 } & 73.3(3) \\
\hline
\end{tabular}

Symmetry codes: ${ }^{i}-x, 1-y, 1-z ;{ }^{\text {ii }} 1-x, 1-y, 1-z$.

Coordination polymer $\left\{\left(\mathrm{Et}_{3} \mathrm{NH}\right)_{2}\left[\mathrm{Bi}(2,3 \text { pydc })(2,3 p y d c H) \mathrm{Cl}_{2}\right]\right\}_{n}(2)$ crystallized in the monoclinic space group $P 2_{1} / c$. Its asymmetric unit comprised one $\mathrm{Bi}(\mathrm{III})$ ion, one molecule of pyridine-2,3dicarboxylato ligand (2,3pydc), one molecule of 3-carboxypyridine-2-carboxylato ligand (2,3pydcH) and two coordinated chloride ions. Compound $\mathbf{2}$ is an anionic polymer, and the negative charge is neutralized by two triethylammonium cations for each Bi(III) center (Figure 2a). In contrast to complex $\mathbf{1}$, the donor atoms in complex 2 were connected with the metal center only by primary bonds $(\mathrm{CN}=8)$, which range from 2.374 to $2.725 \AA$ (Table 2). The chromophore was formed as $\left\{\mathrm{BiO}_{4} \mathrm{~N}_{2} \mathrm{Cl}_{2}\right\}$. The difference in the coordination bond lengths $(0.351 \AA)$ and angles slightly distorted the structure of the coordination environment from an ideal monocapped pentagonal bipyramid. However, a lack of obvious gaps and secondary bonds in the proximity of the Bi(III) center suggested that the lone electron pair was stereochemically inactive or weakly active and did not significantly affect the structure. Consequently, the nearest coordination environment of the Bi(III) center in compound 2 exhibited a holodirected geometry [24].

Additionally, the DFT calculations indicated the conclusion from structural studies. There was a smaller contribution of the $p$ orbital (29.2\%) and a slightly larger contribution of the $s$ orbital $(14.6 \%)$ to the localization of the lone electron pair in the Bi(III) center of compound $\mathbf{2}$ (Figure $2 \mathrm{~b}$ ) compared with the $\mathrm{Bi}(\mathrm{III})$ centers of compound 1 . As a result, the electron density was more centered and insignificantly influenced the structure distortion. 


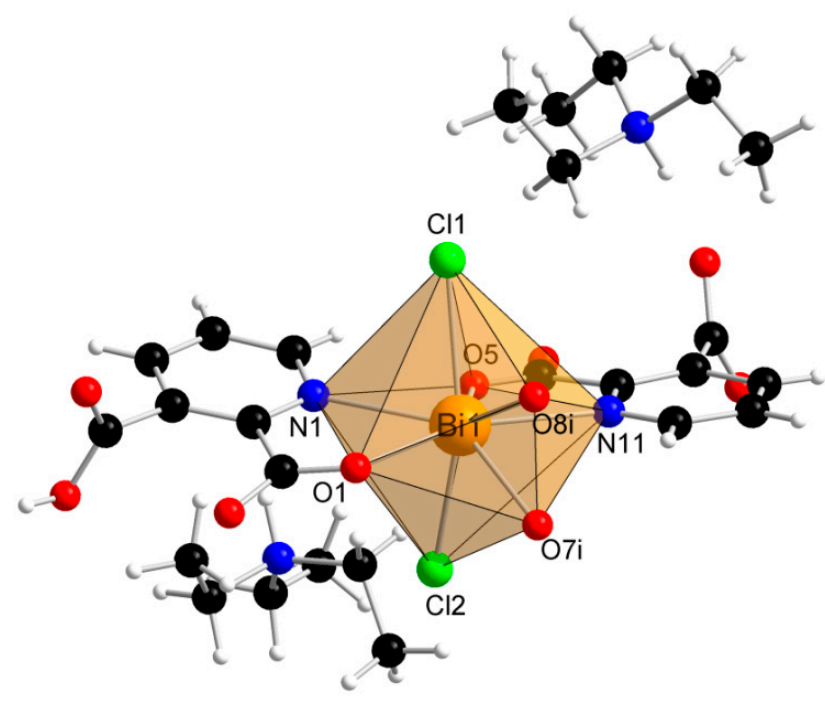

(a)



(b)

Figure 2. (a) The molecular structure with an atom numbering scheme of complex 2 (Symmetry code: (i) $\mathrm{x}, 0.5-\mathrm{y},-0.5+\mathrm{z})(\mathrm{Bi}$-orange, $\mathrm{O}$-red, $\mathrm{N}$-blue, $\mathrm{Cl}$ - green, $\mathrm{C}$-black, $\mathrm{H}$-white); (b) graphical representation of selected molecular orbital localized on Bi atom in complex 2 (DFT calculations).

Table 2. Selected bond lengths $(\AA)$ and angles $\left(^{\circ}\right)$ for complex 2.

\begin{tabular}{|c|c|c|c|c|c|c|c|}
\hline \multicolumn{8}{|c|}{ Bond Lengths (Å) } \\
\hline Bi1-O5 & $2.374(7)$ & Bi1-N1 & $2.546(7)$ & $\mathrm{Bi1}-\mathrm{O} 7^{\mathrm{i}}$ & $2.651(6)$ & Bi1-O8 ${ }^{i}$ & $2.721(7)$ \\
\hline Bi1-O1 & $2.429(7)$ & Bi1-N11 & $2.585(7)$ & $\mathrm{Bi} 1-\mathrm{Cl} 2$ & $2.672(2)$ & Bi1-Cl1 & $2.725(3)$ \\
\hline \multicolumn{8}{|c|}{ Bond Angles $\left({ }^{\circ}\right)$} \\
\hline \multicolumn{2}{|c|}{ O1-Bi1-N1 } & $65.5(2)$ & \multicolumn{2}{|c|}{ N1-Bi1-N11 } & $140.9(2)$ & O5-Bi1-O7 ${ }^{\mathrm{i}}$ & $136.5(2)$ \\
\hline \multicolumn{2}{|c|}{ O1-Bi1-Cl1 } & $97.3(3)$ & \multicolumn{2}{|c|}{$\mathrm{N} 1-\mathrm{Bi} 1-\mathrm{O} 7^{\mathrm{i}}$} & $138.2(2)$ & O5-Bi1-Cl2 & $83.6(8)$ \\
\hline \multicolumn{2}{|c|}{ O1-Bi1-O5 } & 140.5(2) & \multicolumn{2}{|c|}{ N1-Bi1-Cl2 } & $82.8(5)$ & O8 i-Bi1-N11 & $81.3(2)$ \\
\hline \multicolumn{2}{|c|}{ O1-Bi1-O8 ${ }^{\mathrm{i}}$} & $77.5(2)$ & \multicolumn{2}{|c|}{ Cl1-Bi1-O5 } & $83.5(3)$ & $\mathrm{O} 8^{\mathrm{i}}-\mathrm{Bi} 1-\mathrm{O} 7^{\mathrm{i}}$ & $48.4(2)$ \\
\hline \multicolumn{2}{|c|}{ O1-Bi1-N11 } & 153.5(2) & \multicolumn{2}{|c|}{$\mathrm{Cl1}-\mathrm{Bi} 1-\mathrm{O} 8^{\mathrm{i}}$} & $74.3(2)$ & $\mathrm{O} 8{ }^{\mathrm{i}-\mathrm{Bi} 1-\mathrm{Cl} 2}$ & $125.8(5)$ \\
\hline \multicolumn{2}{|c|}{ O1-Bi1-O7 ${ }^{\mathrm{i}}$} & $75.2(2)$ & \multicolumn{2}{|c|}{ Cl1-Bi1-N11 } & $92.0(2)$ & N11-Bi1-O7 ${ }^{\mathrm{i}}$ & $78.8(2)$ \\
\hline \multicolumn{2}{|c|}{ O1-Bi1-C12 } & $82.3(10)$ & \multicolumn{2}{|c|}{$\mathrm{Cl1}-\mathrm{Bi} 1-\mathrm{O} 7^{\mathrm{i}}$} & $122.7(2)$ & N11-Bi1-Cl2 & $97.6(9)$ \\
\hline \multicolumn{2}{|c|}{ N1-Bi1-Cl1 } & $77.8(2)$ & \multicolumn{2}{|c|}{$\mathrm{Cl1}-\mathrm{Bi1}-\mathrm{Cl} 2$} & $158.8(3)$ & $\mathrm{O} 7^{\mathrm{i}-\mathrm{Bi} 1-\mathrm{Cl} 2}$ & $77.9(4)$ \\
\hline \multicolumn{2}{|c|}{ N1-Bi1-O5 } & $76.3(2)$ & \multicolumn{2}{|c|}{ O5-Bi1-O8 ${ }^{\mathrm{i}}$} & $138.8(2)$ & & \\
\hline \multicolumn{2}{|c|}{ N1-Bi1-O8 ${ }^{\mathrm{i}}$} & 129.7(2) & \multicolumn{2}{|c|}{ O5-Bi1-N11 } & $65.1(2)$ & & \\
\hline
\end{tabular}

Symmetry code: ${ }^{\mathrm{i}} \mathrm{x}, 0.5-\mathrm{y},-0.5+\mathrm{z}$.

\subsection{Topology and Supramolecular Structure}

In the structure of coordination polymer 1 , the monoanionic ligand molecules $(2,3 \mathrm{pydcH})$ were connected to the metal center via a chelating $\left(\kappa^{2} \mathrm{~N}, \mathrm{O}\right)$ coordination. In turn, dianionic ligand molecules (2,3pydc) exhibit two kinds of chelating-bridging coordination modes. One of them connects four metal centers according to $\mu_{4}-\mathrm{k}^{2} \mathrm{~N}, \mathrm{O}: \mathrm{KO}^{\prime}: \mathrm{KO}^{\prime \prime}: \mathrm{k}^{2} \mathrm{O}^{\prime \prime}, \mathrm{O}^{\prime \prime \prime}$, while the second one bridges five $\mathrm{Bi}(\mathrm{III})$ centers according to $\mu_{5}-\mathrm{k}^{2} \mathrm{~N}, \mathrm{O}: \mathrm{kO}: \mathrm{kO}^{\prime}: \mathrm{kO}^{\prime \prime}: \mathrm{k}^{2} \mathrm{O}^{\prime \prime}, \mathrm{O}^{\prime \prime \prime}$ (Figure 3a). The water molecule acted as a monocoordinated ligand. Bridging ligand molecules were responsible for the formation of $1 \mathrm{D}$ chains along the $a$ axis with a 4,5C10 topology described by the $\left(4^{5} \cdot 6\right)\left(4^{9} \cdot 6\right)$ point symbol. This type of the underlying net is constructed by 4-connected [Bi1 $\left.(2,3 p y d c H)\left(\mathrm{H}_{2} \mathrm{O}\right)\right]$ and 5 -connected $[\mathrm{Bi} 2(2,3 \mathrm{pydcH})]$ nodes linked together by 4 - and 5-connected [2,3pydc] linkers (Figure $3 \mathrm{~b}$ ). The Bi $\cdots \mathrm{Bi}$ distances ranged from 4.196 to $8.879 \AA$. The relatively short $\mathrm{Bi} \cdots \mathrm{Bi}$ separations (about $4.2 \AA$ ) are close to the sum of the van der Waals radii (4.14 $\AA$ [56]). However, in the structure of $\mathbf{1}$ the shortest Bi $\cdots$ Bi separations are those 
associated with $\mathrm{Bi}_{2} \mathrm{O}_{2}$ dimeric units. They might be considered simply a consequence of the bridging by $\mathrm{O}$-donor carboxylate groups from 2,3pydc linkers and they are not indicative of a $\mathrm{Bi} \cdots \mathrm{Bi}$ bond [57].



$\mu_{5-\mathrm{K}}^{2} \mathrm{~N}, \mathrm{O}: \mathrm{KO}: \mathrm{KO}: \mathrm{KO},: \mathrm{K}^{20},, \mathrm{O}, "$

(a)

(b)

Figure 3. (a) Coordination modes of carboxylate ligands in complex 1; (b) a fragment of the 1D crystal structure merged with 4,5C10 underlying net in valence-bonded MOFs standard representation for coordination polymer $\mathbf{1}$ ( $\mathrm{Bi}$-orange, $\mathrm{O}$-red, $\mathrm{N}$-blue, $\mathrm{C}$-black, $\mathrm{H}$-white).

The supramolecular structure of coordination polymer 1 was stabilized through conventional hydrogen bonding $(\mathrm{O}-\mathrm{H} \cdots \mathrm{O})$ between water molecules and the carboxylate ligands or between the carboxylic groups of the 2,3pydcH molecules and the carboxylate groups of the 2,3pydc ligands with $d(\mathrm{H} \cdots \mathrm{O})$ distances ranging from 1.801 to $2.574 \AA$ (Figure $4 \mathrm{a})$. Nonconventional $(\mathrm{C}-\mathrm{H} \cdots \mathrm{O})$ hydrogen bonds, both intramolecular (Figure $4 \mathrm{~b}$ ) and intermolecular (Figure $4 \mathrm{~d}$ ), also played an important role. Moreover, $\pi$-stacking interactions between pyridine rings were observed in the structure at a distance of $4.043 \AA$ (Figure 4c). The details of the interactions in complex 1 are listed in Table 3 .

In the structure of complex 2, ligand 2,3pydcH exhibited a chelating coordination mode $\left(\kappa^{2} \mathrm{~N}, \mathrm{O}\right)$, while ligand 2,3pydc exhibited a chelating-bridging coordination mode $\left(\mu-\kappa^{2} \mathrm{~N}, \mathrm{O}: \mathrm{k}^{2} \mathrm{O}^{\prime \prime}, \mathrm{O}^{\prime \prime \prime}\right)$ (Figure $5 \mathrm{a}$ ). Compound 2 was a 1-dimensional coordination polymer forming a zig-zag pattern along the $c$ axis. From the topological point of view, this type of connection is described as $2 \mathrm{C} 1$ in the valence-bonded MOFs standard representation. 2-Connected [ $\left.\mathrm{Bi}(2,3 \mathrm{pydcH}) \mathrm{Cl}_{2}\right]$ nodes were combined by 2-connected [2,3pydc] linkers at a distance of $8.909 \AA$. In the H-bonded MOFs standard representation, the topology of complex 2 was changed. Taking into account the strong $\mathrm{O} 4-\mathrm{H} 4 \mathrm{~A} \cdots \mathrm{O} 6^{\mathrm{ii}}$ hydrogen bonds formed between the $-\mathrm{COOH}$ group of the 2,3pydcH ligand and the - $\mathrm{COO}-$ group of the 2,3pydc ligand, the dimensionality increased to 2D ( $b c$ plane). Nodes and linkers became 3-connected, which resulted in the formation of a honeycomb-like hcb net described by the $6^{3}$ point symbol (Figure $5 b$ ). 




(a)

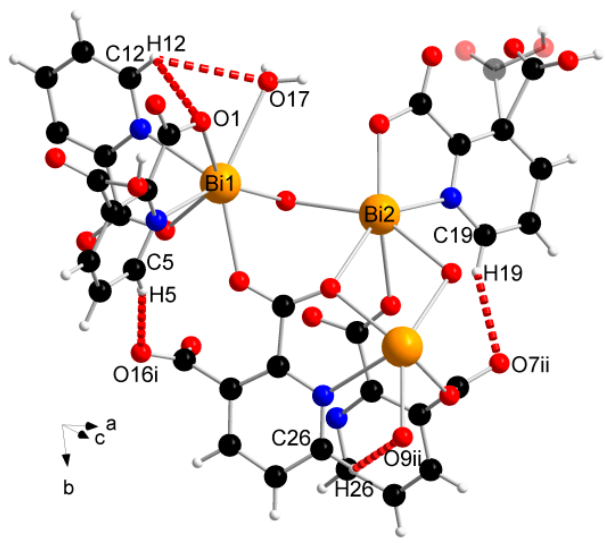

(b)



(c)

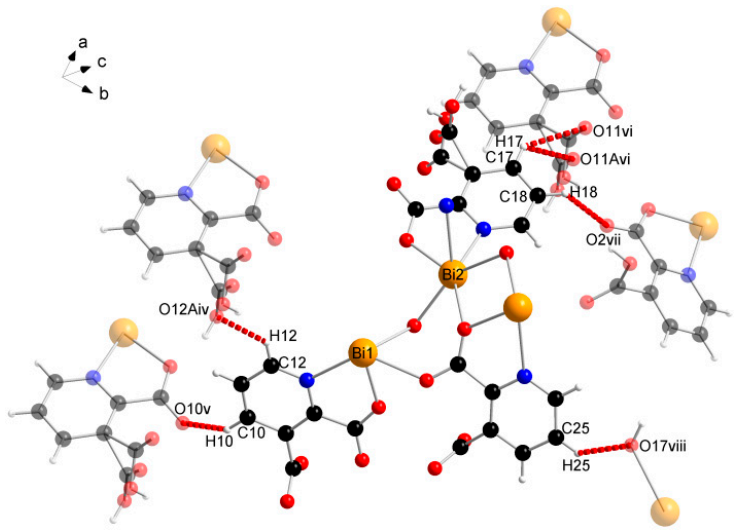

(d)

Figure 4. The geometry of noncovalent interactions in complex 1: (a) $\mathrm{O}-\mathrm{H} \cdots \mathrm{O}$, (b) $\mathrm{C}-\mathrm{H} \cdots \mathrm{O}$ intramolecular, (c) $\pi \cdots \pi$ and (d) $\mathrm{C}-\mathrm{H} \cdots \mathrm{O}$ intermolecular (translucent molecules belong to adjacent chains) (Bi-orange, $\mathrm{O}$-red, $\mathrm{N}$-blue, $\mathrm{C}$-black, $\mathrm{H}$-white).

Table 3. The geometry of noncovalent interactions in complex $\mathbf{1}$.

\begin{tabular}{|c|c|c|c|c|}
\hline \multicolumn{5}{|c|}{ Hydrogen Bonds } \\
\hline Donor-H $\cdots$ Acceptor & D-H (Å) & 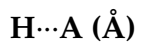 & D...A (Å) & $\mathrm{D}-\mathrm{H} \cdots \mathrm{A}\left({ }^{\circ}\right)$ \\
\hline 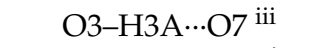 & $0.84(1)$ & $1.801(28)$ & $2.625(37)$ & $166.46(4)$ \\
\hline $\mathrm{O} 12-\mathrm{H} 12 \mathrm{~A} \cdots \mathrm{O} 1 \mathrm{iv}$ & $0.84(1)$ & $2.550(41)$ & $3.171(40)$ & $131.65(5)$ \\
\hline O17-H17B…99 & $0.87(1)$ & $2.574(14)$ & $3.208(30)$ & $130.56(4)$ \\
\hline$\overline{\mathrm{C}} \overline{5}-\overline{\mathrm{H}} \overline{5} \cdots \mathrm{O} 16^{\mathrm{i}}{ }^{-}$ & $0.95(1)$ & $2.220(38)$ & $3.140(51)$ & $\overline{162.68(4)}$ \\
\hline $\mathrm{C} 10-\mathrm{H} 10 \cdots \mathrm{O} 16^{\mathrm{i}}$ & $0.95(1)$ & $2.489(38)$ & $3.310(47)$ & $144.71(5)$ \\
\hline $\mathrm{C} 12-\mathrm{H} 12 \cdots \mathrm{O} 1$ & $0.95(1)$ & $2.542(41)$ & $3.012(42)$ & $110.73(4)$ \\
\hline 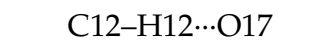 & $0.95(1)$ & $2.926(38)$ & $3.409(51)$ & $112.79(3)$ \\
\hline $\mathrm{C} 12-\mathrm{H} 12 \cdots \mathrm{O} 12 \mathrm{~A}^{\mathrm{iv}}$ & $0.95(1)$ & $2.211(36)$ & $2.957(53)$ & $134.64(4)$ \\
\hline C17-H17…O11 vi & $0.95(2)$ & $2.519(5)$ & $3.313(13)$ & $141.00(3)$ \\
\hline  & $0.95(2)$ & $2.699(41)$ & $3.278(36)$ & 119.81(3) \\
\hline $\mathrm{C} 18-\mathrm{H} 18 \cdots \mathrm{O} 2$ vii & $0.95(2)$ & $2.901(10)$ & $3.496(23)$ & $121.81(3)$ \\
\hline $\mathrm{C} 19-\mathrm{H} 19 \ldots \mathrm{O} 7 \mathrm{ii}$ & $0.95(1)$ & $2.483(20)$ & $3.346(22)$ & $150.44(6)$ \\
\hline 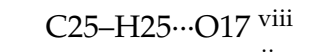 & $0.95(1)$ & $2.639(36)$ & $3.336(38)$ & $130.62(5)$ \\
\hline $\mathrm{C} 26-\mathrm{H} 26 \cdots \mathrm{O} 9 \mathrm{ii}$ & $0.95(1)$ & $2.467(36)$ & $2.948(25)$ & $111.30(4)$ \\
\hline
\end{tabular}

\begin{tabular}{cc}
\hline & $\pi \cdots \pi$ interactions \\
\hline $\mathrm{Cg} \cdots \mathrm{Cg}(\AA)$ \\
\hline $\mathrm{Cg} 1 \cdots \mathrm{Cg} 2$ & $4.043(24)$
\end{tabular}


$-\mathrm{y}, 2-\mathrm{z} ;{ }^{\text {vii }} \mathrm{x}, \mathrm{y}, 1+\mathrm{z} ;{ }^{\text {viii }} \mathrm{x}, 1+\mathrm{y}, \mathrm{z}$. Cg denotes the centre of gravity of the 6-membered pyridine ring. 




(a)

(b)

Figure 5. (a) Coordination modes of carboxylate ligands in complex 2; (b) a fragment of the 1D crystal structure merged with $\mathbf{2 C 1}$ underlying net in valence-bonded MOFs standard representation and a fragment of the $2 \mathrm{D}$ crystal structure merged with hcb underlying the net in $\mathrm{H}$-bonded MOFs standard representation for coordination polymer $\mathbf{2}(\mathrm{Bi}$ - orange, $\mathrm{O}$-red, $\mathrm{N}$-blue, $\mathrm{Cl}$-green, $\mathrm{C}$-black, $\mathrm{H}$-white).

The analysis of the complex 2 crystal structure revealed many noncovalent interactions (Figure 6, Table 4). Between the $1 \mathrm{D}$ chains, strong $\mathrm{O}-\mathrm{H}(\mathrm{COOH}) \cdots \mathrm{O}(\mathrm{COO})$ hydrogen bonds $\left(\mathrm{H} 4 \mathrm{~A} \cdots \mathrm{O} 6^{\mathrm{ii}}=1.727 \AA\right)$ were formed (Figure 6a). Compound 2 was also stabilized by intra- and interchain $\mathrm{C}-\mathrm{H} \cdots \mathrm{O} \cdot \mathrm{O}$ hydrogen bonds with $d(\mathrm{H} \cdots \mathrm{O})$ distances ranging from 2.408 to $2.846 \AA$. The presence of triethylammonium cations in the structure was the source of many donor $\mathrm{C}-\mathrm{H}$ and $\mathrm{N}-\mathrm{H}$ groups, which were the basis of a strong hydrogen-bonded net. The stronger bonds were the $\mathrm{N}-\mathrm{H}\left(\mathrm{Et}_{3} \mathrm{NH}\right) \cdots \mathrm{O}(\mathrm{COO})$ bonds formed at $d(\mathrm{H} \cdots \mathrm{N}$ ) distances of 1.742 and $1.752 \AA$ (Figure $6 \mathrm{~b}$ ). In turn, coordinated chloride ions served as acceptors in the formation of four-furcated $\mathrm{C}-\mathrm{H} \cdots \mathrm{Cl}$ hydrogen bonds with $\mathrm{Et}_{3} \mathrm{NH}$ cations (Figure 6c). Donor $\mathrm{C}-\mathrm{H}$ groups of $\mathrm{Et}_{3} \mathrm{NH}$ molecules also formed interactions with carboxylate oxygen atoms at $d(\mathrm{H} \cdots \mathrm{O})$ distances of $2.554-2.999 \AA$ (Figure $6 \mathrm{~d}$ ). Weak nonconventional $\mathrm{C}-\mathrm{H} \cdots \pi$ hydrogen bond type III according to Malone [58] was also found (Figure 6d).

\subsection{FT-IR Analysis}

The FT-IR analysis results of pyridine-2,3-dicarboxylic acid and bismuth(III) complexes $\mathbf{1}$ and $\mathbf{2}$ are summarized in Table S1. An interesting phenomenon of this acid worth mentioning is that it exists in its zwitterionic form in the solid-state. Therefore, in the free ligand spectrum, we observed a band derived from protonated pyridine nitrogen $\left(v(\mathrm{~N}-\mathrm{H})_{\mathrm{pyH}}\right)$ and a broad band of $\mathrm{O}-\mathrm{H}$ stretching vibrations attributed to intramolecular hydrogen bonds between the carboxylate groups [48,59,60]. The infrared spectra of bismuth coordination polymers 1 and 2 (Figure 7) contained the bands derived from the vibrations $v(\mathrm{C}=\mathrm{O})_{\mathrm{COOH}}$ at 1727 and $1708 \mathrm{~cm}^{-1}$, respectively, as well as the vibrations $v_{\mathrm{as}}(\mathrm{COO})$ and $v_{\mathrm{S}}(\mathrm{COO})$ (Table S1). This spectral pattern indicated that one of the carboxylic groups of the ligand was deprotonated while the second one remained deprotonated (mono-deprotonated-2,3pydcH anion), or both carboxylic groups were deprotonated (doubly deprotonated-2,3pydc anion). The $\Delta v$ values of the carboxylate stretching frequencies $\left[\Delta v=v_{\text {as }}(\mathrm{COO})-v_{\mathrm{s}}(\mathrm{COO})\right]$ [61] were 246, 202 and $165 \mathrm{~cm}^{-1}$ in the spectrum of complex 1 and 249 and $182 \mathrm{~cm}^{-1}$ in the spectrum of complex 2, indicating the different coordination modes of the carboxylates in these compounds. According to Deacon and Phillips [61], the value $\Delta v>200 \mathrm{~cm}^{-1}$ indicated a bridging mode of ligand binding, while $\Delta v<200 \mathrm{~cm}^{-1}$ 
indicated a bidentate chelating mode. In addition, the FT-IR spectra provided further evidence for the formation of a coordination bond between the $\mathrm{Bi}(\mathrm{III})$ ion and the pyridine nitrogen atom by means of a relative shift in the absorbance of the $v(\mathrm{C}=\mathrm{N})$ band (see Table S1) and a strong absorption band at $634-624 \mathrm{~cm}^{-1}[35,62]$. Additionally, in the spectrum of compound 1, a wide band in the range $3600-3200 \mathrm{~cm}^{-1}$ from $v(\mathrm{O}-\mathrm{H})$ vibrations corresponding to the water molecules engaged in hydrogen bonds was observed. On the other hand, in the spectrum of compound 2, additional bands appeared at 2712 and $2511 \mathrm{~cm}^{-1}$ and at $1272 \mathrm{~cm}^{-1}$, which were attributed to the $v(\mathrm{~N}-\mathrm{H})$ and $v(\mathrm{C}-\mathrm{N})$ vibrations. These bands suggested the presence of protonated triethylammonium $\left(\mathrm{Et}_{3} \mathrm{NH}\right)$ ions in the complex structure. Thus, spectroscopic analysis showed a good correlation with the structural X-ray analysis results of the analyzed complexes (vide supra).

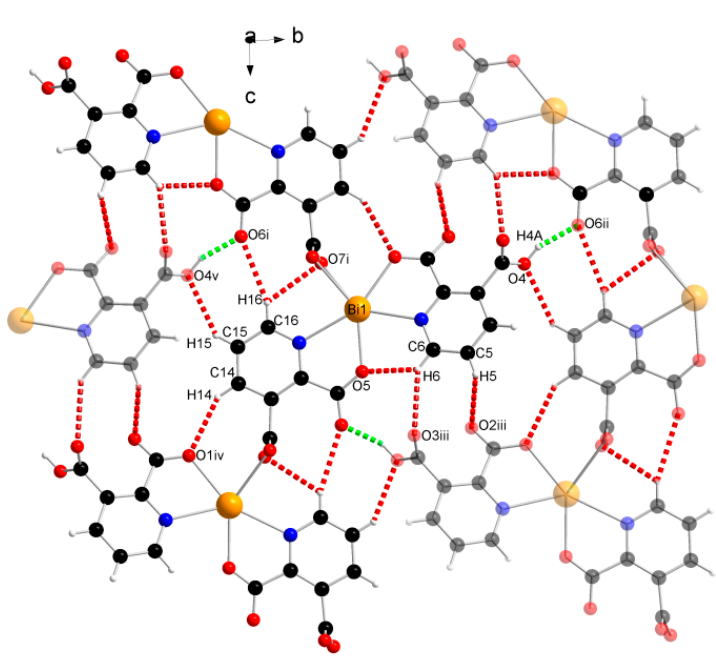

(a)



(b)

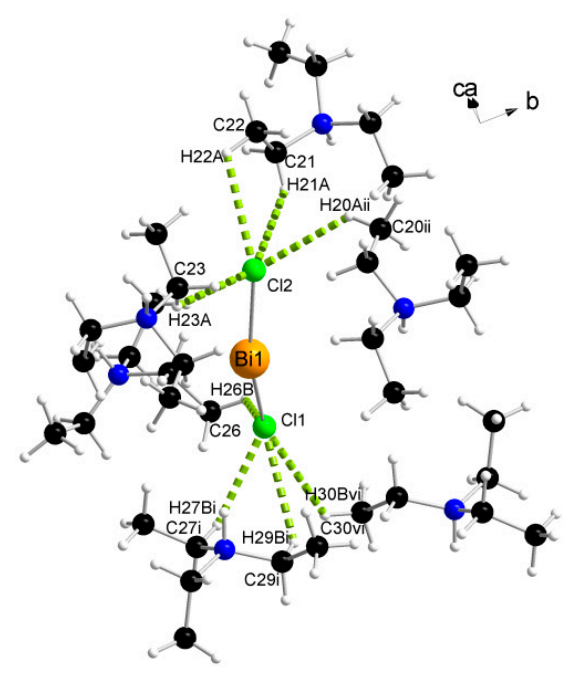

(c)



(d)

Figure 6. The geometry of noncovalent interactions in complex 2: (a) $\mathrm{O} / \mathrm{C}-\mathrm{H} \cdots \mathrm{O}$ formed between adjacent polymeric chains, (b) $\mathrm{N}-\mathrm{H} \cdots \mathrm{O}$, (c) $\mathrm{C}-\mathrm{H} \cdots \mathrm{Cl}$ and (d) $\mathrm{C}-\mathrm{H} \cdots \mathrm{O} / \pi$ formed between $\mathrm{Et}_{3} \mathrm{NH}$ cations and polymeric chains (translucent molecules belong to adjacent chains) (Bi-orange, $\mathrm{O}-$ red, $\mathrm{N}-$ blue, $\mathrm{Cl}$-green, $\mathrm{C}$-black, $\mathrm{H}$-white). 
Table 4. The geometry of noncovalent interactions in complex 2.

\begin{tabular}{|c|c|c|c|c|c|}
\hline \multicolumn{6}{|c|}{ Hydrogen Bonds } \\
\hline \multicolumn{2}{|c|}{ Donor-H $\cdots$ Acceptor } & D-H (̊̊) & $\mathbf{H} \cdots \mathbf{A}(\AA)$ & 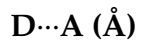 & D-H $\cdots A\left({ }^{\circ}\right)$ \\
\hline \multirow{8}{*}{ Interchain } & $\mathrm{O} 4-\mathrm{H} 4 \mathrm{~A} \cdots \mathrm{O} 6^{\mathrm{ii}}$ & 0.84 & $1.727(1)$ & $2.533(1)$ & 160.08 \\
\hline & $\mathrm{C} 5-\mathrm{H} 5 \cdots \mathrm{O} 2{ }^{\mathrm{iii}}$ & 0.95 & $2.846(6)$ & $3.281(6)$ & 109.03 \\
\hline & $\mathrm{C} 6-\mathrm{H} 6 \cdots \mathrm{O} 33^{\mathrm{iii}}$ & 0.95 & $2.654(3)$ & $3.460(3)$ & 143.04 \\
\hline &  & 0.95 & $2.408(1)$ & $3.025(1)$ & 122.36 \\
\hline & $\mathrm{C} 14-\mathrm{H} 14 \cdots \mathrm{O} 1^{\text {iv }}$ & 0.95 & $2.585(2)$ & $3.399(2)$ & 143.88 \\
\hline & $\mathrm{C} 15-\mathrm{H} 15 \cdots \mathrm{O} 4{ }^{\mathrm{v}}$ & 0.95 & $2.545(2)$ & $3.323(1)$ & 139.22 \\
\hline & $\mathrm{C} 16-\mathrm{H} 16 \cdots \mathrm{O}^{\mathrm{i}}$ & 0.95 & $2.689(1)$ & $3.598(1)$ & 160.22 \\
\hline & $\mathrm{C} 16-\mathrm{H} 16 \cdots \mathrm{O}^{\mathrm{i}}$ & 0.95 & $2.661(2)$ & $3.280(2)$ & 123.17 \\
\hline \multirow{21}{*}{$\begin{array}{c}\text { Between } \mathrm{Et}_{3} \mathrm{NH} \text { and } \\
\text { polymeric chain }\end{array}$} & $\mathrm{N} 2{ }^{\mathrm{ii}-\mathrm{H}} 2{ }^{\mathrm{ii}} \ldots \mathrm{O} 2$ & 1.00 & $1.742(1)$ & $2.740(2)$ & 174.95 \\
\hline &  & 1.00 & $1.752(2)$ & 2.701(3) & 156.94 \\
\hline & $\mathrm{C} 26-\mathrm{H} 26 \mathrm{~B} \cdots \mathrm{Cl} 1$ & 0.97 & $2.801(4)$ & $3.523(5)$ & 131.09 \\
\hline &  & 0.99 & $2.778(3)$ & $3.507(3)$ & 130.83 \\
\hline & $\mathrm{C} 29^{\mathrm{i}}-\mathrm{H} 29 \mathrm{~B}^{\mathrm{i}} \ldots \mathrm{Cl} 1$ & 0.98 & $3.004(5)$ & $3.696(5)$ & 128.49 \\
\hline & C30 vi_H30B vi...Cl1 & 0.98 & $3.058(2)$ & $3.745(2)$ & 128.29 \\
\hline & $\mathrm{C} 20^{\text {ii_-H20A }}{ }^{\text {ii } \ldots \mathrm{Cl} 2}$ & 0.98 & $1.992(1)$ & $2.458(3)$ & 106.68 \\
\hline & $\mathrm{C} 21-\mathrm{H} 21 \mathrm{~A} \cdots \mathrm{Cl} 2$ & 0.99 & $2.925(1)$ & $3.615(2)$ & 127.11 \\
\hline & $\mathrm{C} 22-\mathrm{H} 22 \mathrm{~A} \cdots \mathrm{Cl} 2$ & 0.99 & $2.986(2)$ & $3.609(4)$ & 121.93 \\
\hline & $\mathrm{C} 23-\mathrm{H} 23 \mathrm{~A} \cdots \mathrm{Cl} 2$ & 0.99 & $3.052(1)$ & $4.012(2)$ & 163.96 \\
\hline & C19 vii_H19A vii...O7 & 0.99 & $2.554(4)$ & $3.410(5)$ & 144.9 \\
\hline & 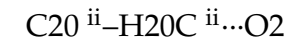 & 0.98 & $2.986(5)$ & $3.640(5)$ & 125.41 \\
\hline & C22 vii_H22B vii...O6 & 0.98 & $2.766(3)$ & $3.549(6)$ & 137.45 \\
\hline & 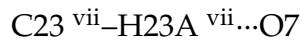 & 0.99 & $2.624(4)$ & $3.475(3)$ & 144.18 \\
\hline & 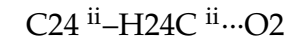 & 0.98 & $2.840(3)$ & $3.544(6)$ & 129.43 \\
\hline &  & 0.99 & $2.922(1)$ & $3.396(2)$ & 110.41 \\
\hline &  & 0.98 & $2.642(4)$ & $3.610(6)$ & 170.72 \\
\hline & $\mathrm{C} 27^{\text {vi_H}}-\mathrm{H} 27 \mathrm{~A}^{\mathrm{vi}} \ldots \mathrm{O} 3$ & 0.99 & $2.606(3)$ & $3.594(4)$ & 175.75 \\
\hline & $\mathrm{C} 28-\mathrm{H} 28 \mathrm{~B} \cdots \mathrm{O} 8$ & 0.98 & 2.999(3) & $3.600(3)$ & 120.91 \\
\hline & С30-Н30С …8 & 0.99 & $2.919(6)$ & $3.640(8)$ & 130.61 \\
\hline & $\mathrm{C} 24-\mathrm{H} 24 \mathrm{C} \cdots \mathrm{Cg}^{\mathrm{ii}}$ & 0.98 & $2.967(5)$ & $3.627(5)$ & 125.63 \\
\hline
\end{tabular}

Symmetry codes: ${ }^{\mathrm{i}} \mathrm{x}, 0.5-\mathrm{y},-0.5+\mathrm{z} ;{ }^{\mathrm{ii}} \mathrm{x}, 1.5-\mathrm{y},-0.5+\mathrm{z} ;{ }^{\text {iii }} \mathrm{x}, 1.5-\mathrm{y}, 0.5+\mathrm{z} ;{ }^{\text {iv }} \mathrm{x}, 0.5-\mathrm{y}, 0.5+\mathrm{z} ;{ }^{\mathrm{v}} \mathrm{x},-1+\mathrm{y}$, $z^{;}{ }^{\mathrm{vi}}-\mathrm{x}, 0.5+\mathrm{y}, 1.5-\mathrm{z} ;{ }^{\mathrm{vii}} 1-\mathrm{x}, 1-\mathrm{y}, 2-\mathrm{z}$. Cg denotes the centre of gravity of the 6-membered pyridine ring. $\mathrm{Et}_{3} \mathrm{NH}$ - triethylammonium cation.<smiles>O=C(O)c1cccnc1C(=O)O</smiles><smiles></smiles>



(a)

(b)

Figure 7. Cont. 




(c)

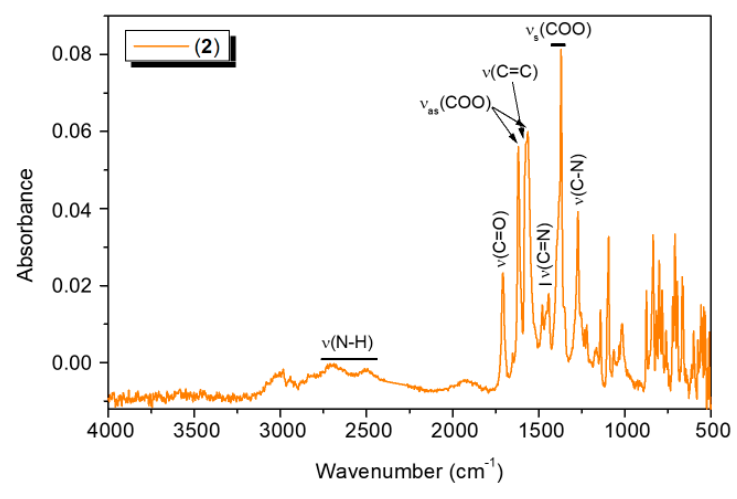

(d)

Figure 7. (a) The non-zwitterionic and zwitterionic form of 2,3pydcH $\mathrm{H}_{2}$; the FT-IR spectra of: (b) 2,3pydcH ${ }_{2}$, (c) complex 1 and (d) complex 2.

\subsection{Thermal Analysis}

To determine the thermal stability of the Bi(III) complexes, thermogravimetric analysis was carried out. Coordination polymer $\mathbf{1}$ was stable at temperatures up to $35^{\circ} \mathrm{C}$, and the first decomposition step was attributed to the loss of water molecules (1.59\%, calcd: $1.64 \%$ ) (Figure $8 \mathrm{a})$. Next, at temperatures up to $450{ }^{\circ} \mathrm{C}$, we observed the gradual decomposition of the coordinating mono-deprotonated and deprotonated pyridine-2,3-dicarboxylate anions (55.68\%, calcd: $55.92 \%)$. At the end of this process, $\mathrm{Bi}_{2} \mathrm{O}_{3}$ remained as a final residue $(42.73 \%$, calcd: $42.44 \%)$. Polymer 2 was stable up to approximately $140{ }^{\circ} \mathrm{C}$ and then decomposed in two main stages (Figure 8b). The first stage involved the thermal dissociation of the two lattice triethylammonium cations (25.49\%, calcd: $25.06 \%)$, which were bound to the coordination polymer chain by hydrogen bonds. In the next stage, which took place in the temperature range of $210-450{ }^{\circ} \mathrm{C}$, the whole polymer was decomposed (observed: $46.29 \%$, calcd: $46.37 \%)$. The product of the thermal decomposition of 2 was $\mathrm{Bi}_{2} \mathrm{O}_{3}(28.22 \%$, calcd: $28.57 \%)$.

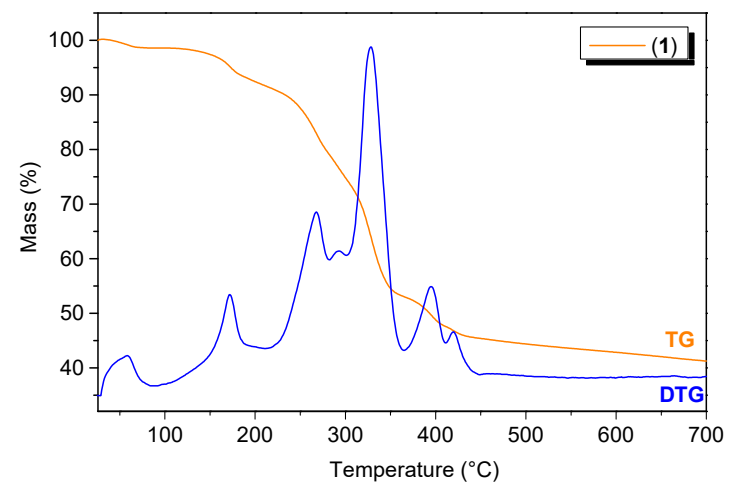

(a)



(b)

Figure 8. The TG/DTG curves for (a) compound $\mathbf{1}$ and (b) compound $\mathbf{2}$.

\subsection{Photoluminescence Properties}

To establish the photoluminescence properties of the newly obtained Bi(III) coordination polymers 1 and 2, 3D and 2D room temperature solid-state excitation/emission spectra were recorded (Figure 9). Pyridine-2,3-dicarboxylic acid exhibited blue light emission with a maximum at $459 \mathrm{~nm}$ after excitation at $419 \mathrm{~nm}$ (Figure 9a). The emission of the ligand was attributed to the intraligand (IL) $n \rightarrow \pi^{*}$ transitions [63]. The excitation spectrum of 2,3 $\mathrm{pydcH}_{2}$ contained an additional band without a distinct 
maximum below $400 \mathrm{~nm}$, which was attributed to the higher energy $\pi \rightarrow \pi^{*}$ transitions. Comparing the 3D spectrum of compound 1 (Figure $9 \mathrm{~b}$ ) with the $2,3 \mathrm{pydcH}_{2}$ spectrum, the emission centers were located at similar wavelengths. The emission maximum at $452 \mathrm{~nm}\left(\lambda_{\mathrm{ex}}=413 \mathrm{~nm}\right)$ was only slightly blue-shifted $(7 \mathrm{~nm})$ in the spectrum of complex 1 compared to the ligand. The emission band was characterized by a similar ligand Stokes shift $(39 \mathrm{~nm})$, which pointed to the intraligand type of electronic transitions in complex 1 . The shoulder at ca. $470 \mathrm{~nm}$ indicated the presence of two types of ligand in the structure (mono-deprotonated and fully deprotonated), which coordinated to Bi(III) ions in different fashions. Thus, constructed in this way, the polymeric structure is characterized by a different rigidity, which influences the energy of emission. Similarly, compound 2 exhibited blue luminescence with a maximum at 463 and $471 \mathrm{~nm}$ after excitation at $362 \mathrm{~nm}$ (Figure 9c). Moreover, a significant Stokes shifts (101 and $109 \mathrm{~nm}$ ) of coordination polymer 2, accompanying by similar excitation wavelength compared to the ligand, suggested that the emission of $\mathbf{2}$ can be attributed to a ligand-to-metal charge transfer transition (LMCT), as well as to a change in the intraligand transitions (IL) $[27,32,64]$. The photoluminescence quantum yield of complex 2 was $8.36 \%$, which makes it a good candidate for more specific studies of Bi-based fluorescent materials [62,65].
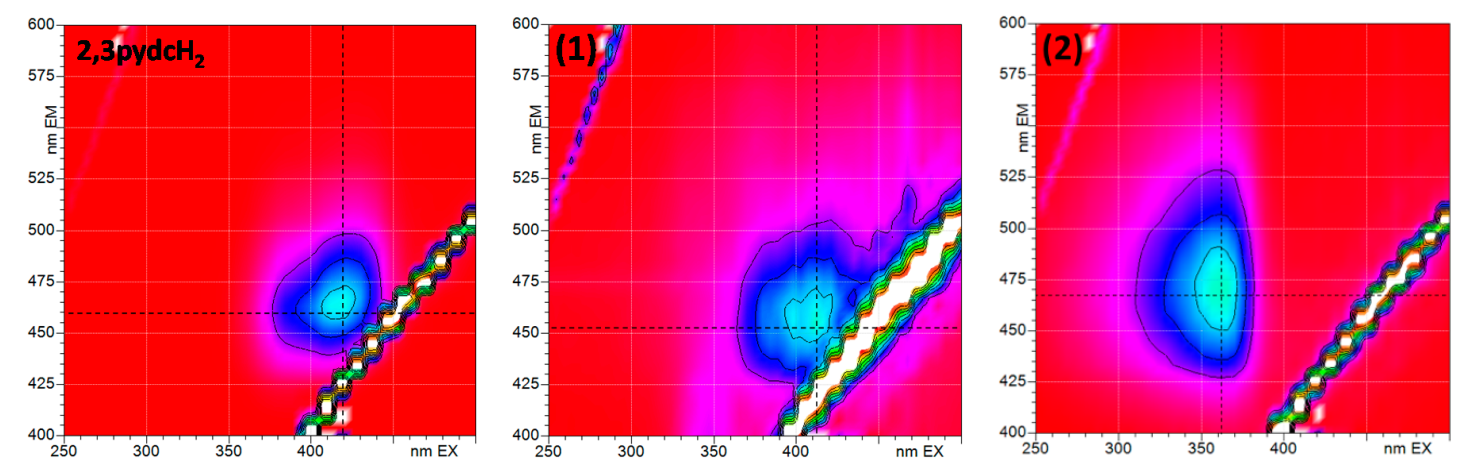

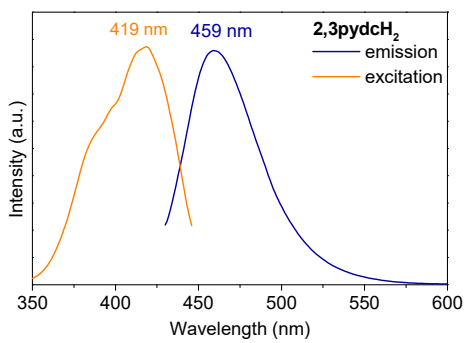

(a)

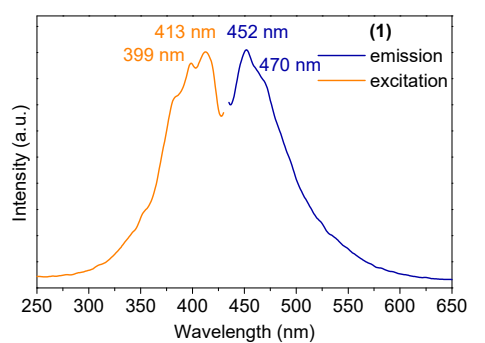

(b)

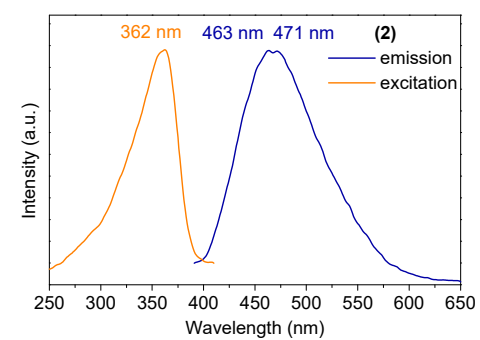

(c)

Figure 9. The solid-state 3D (top) and 2D (bottom) photoluminescence spectra of: (a) 2,3pydcH ${ }_{2}$, (b) compound 1 and (c) compound 2.

\subsection{Solubility and Stability}

Solubility and stability studies are important in the process of developing biologically active compounds. The ligand 2,3pydc $\mathrm{H}_{2}$ is soluble in $\mathrm{H}_{2} \mathrm{O}, 1 \mathrm{M} \mathrm{HCl}, \mathrm{MeOH}, \mathrm{EtOH}, \mathrm{DMF}$ and DMSO, partly soluble in ${ }^{\mathrm{i}} \mathrm{PrOH}$ and $\mathrm{MeCN}$, and insoluble in $\mathrm{Me}_{2} \mathrm{CO}$, THF and $\mathrm{CH}_{2} \mathrm{Cl}_{2}$. However, coordination polymers 1 and 2 were soluble only in DMSO and $1 \mathrm{M} \mathrm{HCl}$ but insoluble in the other tested solvents. An important advantage of the tested bismuth compounds was their solubility in DMSO without subsequent precipitation after diluting it with water. It is an essential feature of compounds in further biological studies conducted against Helicobacter pylori.

It is also important to examine the stability of analyzed compounds in the media used in the anti-H. pylori experiments. All tested compounds $\left(2,3 \mathrm{pydcH}_{2}\right.$, complexes $\mathbf{1}$ and 2$)$ were stable for $48 \mathrm{~h}$ when dissolved in DMSO and then diluted with $\mathrm{H}_{2} \mathrm{O}(1: 50 \mathrm{v} / \mathrm{v})$. According to the time-dependent 
UV-Vis spectra (Figure 10 (top)), there were no obvious changes in the positions of the absorption bands $( \pm 1 \mathrm{~nm})$ and no significant decrease in absorbance. The absorption maxima were located at 236 and $274 \mathrm{~nm}$ for complex $\mathbf{1}$ and at 237 and $275 \mathrm{~nm}$ for complex 2 (Figure 10b,c (top)); the maxima were located almost at the same positions as the maxima in the ligand spectrum ( 234 and $275 \mathrm{~nm}$ ) (Figure 10a (top)). Comparing the free ligand spectrum with the electronic spectra of complexes $\mathbf{1}$ and 2 showed the main bands corresponding to the ligand centered in the $\pi \rightarrow \pi^{*}$ and $n \rightarrow \pi^{*}$ transitions. Therefore, it can be assumed that there were no structural changes of the compounds upon their reaction with solvent (DMSO and $\mathrm{H}_{2} \mathrm{O}$ ) molecules.
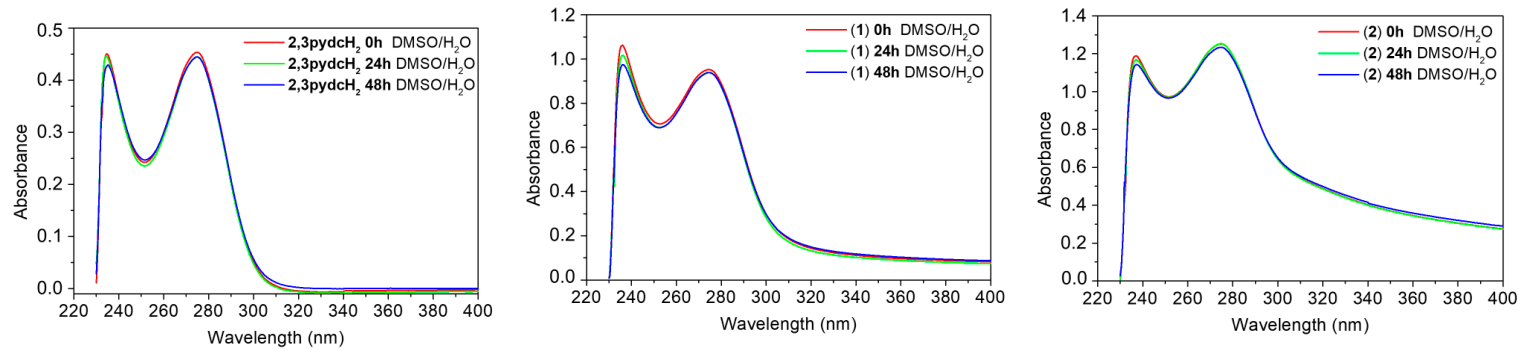

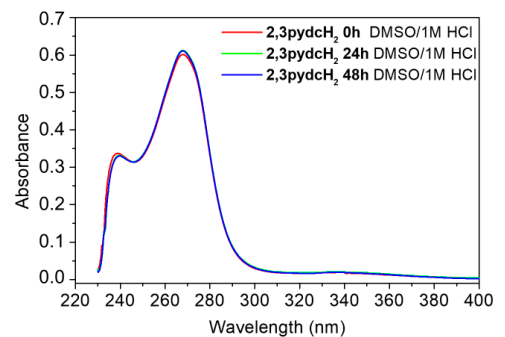

(a)



(b)

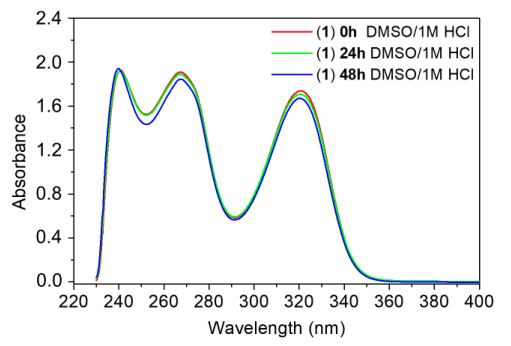

(c)

Figure 10. Time-dependent $\left(0 \mathrm{~h}, 24 \mathrm{~h}\right.$ and $48 \mathrm{~h}$ ) stability studies on: (a) 2,3pydcH $\mathrm{H}_{2}$, (b) complex 1, (c) complex 2 in DMSO/ $\mathrm{H}_{2} \mathrm{O}$ 1:50 (v/v) (top) and DMSO/1M HCl 1:50 (v/v) (bottom) solutions monitored by UV-Vis absorption spectra.

Additionally, it is important to examine the behavior of complexes $\mathbf{1}$ and $\mathbf{2}$ in acidic medium, taking into consideration that the compounds would be exposed to stomach acid in vivo if used as drugs [66]. After dissolving the compounds in $1 \mathrm{M} \mathrm{HCl}$ solution, the UV-vis spectra showed an additional absorption band near $321 \mathrm{~nm}$, which confirmed that the complexes released organic acids and $\mathrm{Bi}^{3+}$ ions, which remained soluble in $\mathrm{HCl}$ solution as $\mathrm{BiOCl}$ [67]. A similar $\mathrm{UV}$-Vis spectrum was recorded for the model reaction of $\mathrm{BiCl}_{3}$ with $\mathrm{H}_{2} \mathrm{O}$ in a $1 \mathrm{M} \mathrm{HCl}$ solution (Figure S1).

\subsection{Antibacterial Activity towards Helicobacter Pylori}

Infection with $H$. pylori bacteria contributes to the development of three serious digestive diseases, namely, gastric and duodenal ulcers, gastric cancer and MALT-type gastric lymphoma. The discovery of this relationship has led to extensive research regarding the application of bismuth compounds in the treatment of microbial infections [21,40]. The most important research studies include Bi(III) complexes with non-steroidal anti-inflammatory drugs [68], indolocarboxylates [67], salicylates [69-71], sulfonates [72-74], (thio)saccharinates [75], acetosulfame and cyclamic acid [76] and (benzo)hydroxamic acids $[77,78]$. Most of the compounds from these groups are heteroleptic organometallic complexes, including oxoclasters. A great advantage of the use of bismuth-based drugs is the lack of H. pylori resistance towards these drugs [22,41,79-81]. These studies inspired us to examine the antimicrobial properties of new polymeric $\mathrm{Bi}(\mathrm{III})$ complexes with low-molecular weight $\mathrm{N}$-heteroaromatic carboxylic acids against Helicobacter pylori. 
An analysis of the obtained results (Figure 11) revealed that the ligand 2,3pydcH $\mathrm{H}_{2}$ was inactive against both $H$. pylori strains (26695 and N6), even at high concentrations (MIC > $100 \mu \mathrm{M}$ ). Both Bi(III) complexes exhibited bacteriostatic effects towards H. pylori. The MIC values of $\mathbf{1}$ and $\mathbf{2}$ towards reference strain 26695 reached values of 13.7 and $36.8 \mu \mathrm{M}$, respectively. The results indicated that the compound 1 was about twice as potent against $H$. pylori than the commercially used Bi-based drug BSS $(\mathrm{MIC}=34.5 \mu \mathrm{M})$. Moreover, strain N6 was slightly more sensitive to compound $\mathbf{1}(\mathrm{MIC}=11.4 \mu \mathrm{M})$ and compound 2 (MIC $=24.5 \mu \mathrm{M})$ than strain 26695. Generally, compound 1 was more than twice as active against $H$. pylori as compound 2 . It can be concluded that the presence of chloride and triethylammonium ions in the structure of complex 2 pointed out the anionic form of Bi(III) complex, which influenced its antibacterial activity. The anionic form of complex $\mathbf{2}$ is more difficult to penetrate the negatively charged cell membrane of the H. pylori bacteria.



Figure 11. Antibacterial activity of $\left[\mathrm{Bi}_{2}(2,3 \text { pydc })_{2}(2,3 \text { pydcH })_{2}\left(\mathrm{H}_{2} \mathrm{O}\right)\right]_{\mathrm{n}}(\mathbf{1}),\left\{\left(\mathrm{Et}_{3} \mathrm{NH}\right)_{2}[\mathrm{Bi}(2,3 p y d c)\right.$ $(2,3$ pydcH $\left.\left.) \mathrm{Cl}_{2}\right]\right\}_{\mathrm{n}}(2)$, pyridine-2,3-dicarboxylic acid $\left(2,3\right.$ pydcH $\left.\mathrm{H}_{2}\right)$ and bismuth subsalicylate (BSS) against $H$. pylori strains 26695 and N6.

Comparing the antimicrobial activity of $\mathbf{1}$ and $\mathbf{2}$ with literature data for Bi(III)-carboxylate complexes, it was concluded that the obtained compounds exhibited a slightly smaller bacteriostatic effect towards $H$. pylori (Table 5). The reason for the lower activity could be explained by taking into consideration the polymeric form of the complexes and the different coordination environments, including not only oxygen but also nitrogen/chloride donor atoms and much more complicated forms of coordination polyhedra. 
Table 5. Antibacterial activity of Bi(III) carboxylate complexes against Helicobacter pylori strain 26695.

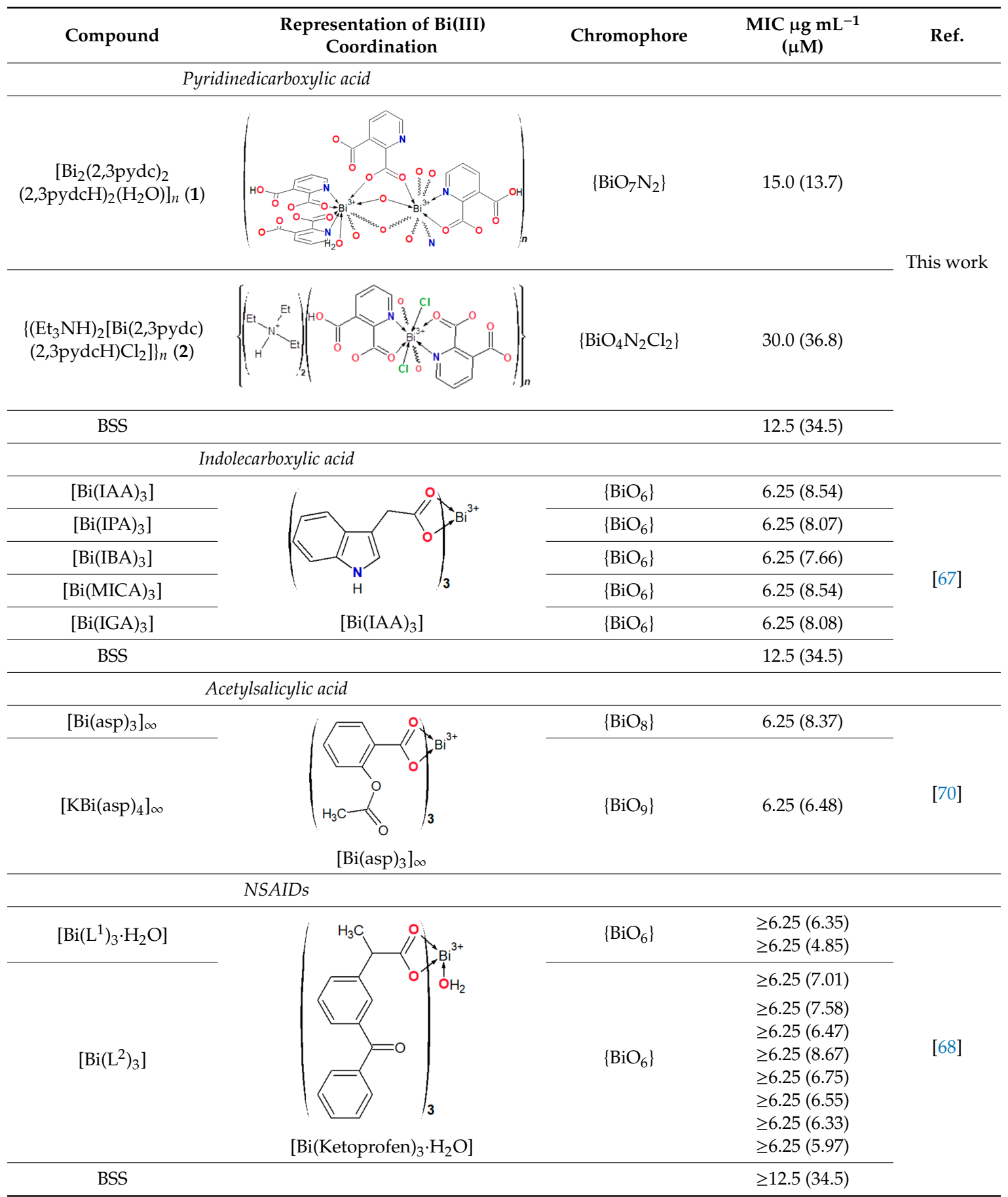

2,3pydcH $\mathrm{H}_{2}$-pyridine-2,3-dicarboxylic acid; $\mathrm{Et}_{3} \mathrm{~N}$-triethylamine; BSS-bismuth subsalicylate; IAA-H-2(1H-indol-3-yl)acetic acid, IPA-H-3-(1H-indol-3-yl)propanoic acid, IBA-H-4-(1H-indol-3-yl))butanoic acid, IGA-H-2-(1H-indol-3-yl))-2-oxoacetic acid, MICA-H-1-methyl- $1 \mathrm{H}$-indole-3-carboxylic acid; aspH-acetylsalicylic acid; NSAIDs: L L $^{1}$ : Ketoprofen, Sulindac; L ${ }^{2}$ : Naproxen, Ibuprofen, Fenbufen, 5-Chlorosalicylic acid, Mefenamic acid, Diflunisal, Tolfenamic acid, Flufenamic acid.

\section{Experimental}

\subsection{Materials and Physicochemical Measurements}

Chemical reagents were purchased commercially and used as received without further purification; $\mathrm{Bi}\left(\mathrm{NO}_{3}\right)_{3} \cdot 5 \mathrm{H}_{2} \mathrm{O}$ (POCH S.A., Gliwice, Poland), $\mathrm{BiCl}_{3}$ (Sigma-Aldrich, Steinheim, 
Germany), pyridine-2,3-dicarboxylic acid (Sigma-Aldrich, Steinheim, Germany), triethylamine (POCH S.A., Gliwice, Poland) and all organic solvents (Chempur, Piekary Śląskie, Poland). Elemental analysis (CHNS) was performed on an Elementar Vario Micro Cube analyzer (Elementar, Langenselbold, Germany). FT-IR spectra were recorded on a Nicolet 380 FT-IR type spectrophotometer (Thermo Scientific, Waltham, MA, USA), in the spectral range $4000-500 \mathrm{~cm}^{-1}$, using the ATR-diffusive reflection method. The thermal analysis (TG/DTG) was carried out using a TG/SDTA $851^{\mathrm{e}}$ Mettler-Toledo thermobalance (Columbus, OH, USA). The experiments were performed in air atmosphere, at a heating rate of $5{ }^{\circ} \mathrm{C} \mathrm{min}-1$, in the temperature range of $25-700{ }^{\circ} \mathrm{C}$, using $\alpha-\mathrm{Al}_{2} \mathrm{O}_{3}$ crucible.

\subsection{Synthesis of $\left[B i_{2}(2,3 p y d c)_{2}(2,3 p y d c H)_{2}\left(\mathrm{H}_{2} \mathrm{O}\right)\right]_{n}(\mathbf{1})$}

An aqueous solution $(30 \mathrm{~mL})$ of pyridine-2,3-dicarboxylic acid $(0.75 \mathrm{mmol}, 0.1253 \mathrm{~g})$ was heated to about $100{ }^{\circ} \mathrm{C}$. Next solid bismuth(III) nitrate $(0.25 \mathrm{mmol}, 0.1213 \mathrm{~g})$ was added to the boiling solution. The resulting mixture was stirred and heated under a reflux for $8 \mathrm{~h}$, after which it was filtered off. The clear filtrate was left to crystallize slowly at room temperature. After a week, colourless crystals were formed, collected by filtration and dried under vacuum $(\mathrm{m}=0.0321 \mathrm{~g}(0.0292 \mathrm{mmol})$, yield: $23 \%$, based on $\mathrm{Bi}(\mathrm{III})$ salt) (Scheme 2). Elemental analysis calculated for $\mathrm{C}_{28} \mathrm{H}_{16} \mathrm{~N}_{4} \mathrm{O}_{17} \mathrm{Bi}_{2}\left(\mathrm{M}_{\mathrm{r}}=1098.41\right)(\%)$ : C 30.62, H 1.47, N 5.10; found: C 30.43, H 1.40, N 5.17; FT-IR ( $\left.\mathrm{cm}^{-1}\right)$ : 3600-3200 (vb), 2887 (w), 1727 (m), $1657(\mathrm{~m}), 1618(\mathrm{~m}), 1604(\mathrm{~m}), 1574(\mathrm{~s}), 1537(\mathrm{~m}), 1449(\mathrm{w}), 1372(\mathrm{~s}), 1280(\mathrm{~m}), 1254(\mathrm{w}), 1230(\mathrm{~m})$, $1149(\mathrm{w}), 1099(\mathrm{~s}), 1071(\mathrm{w}), 1003(\mathrm{w}), 875(\mathrm{w}), 834(\mathrm{~m}), 819(\mathrm{~m}), 798(\mathrm{w}), 778(\mathrm{w}), 697(\mathrm{~s}), 667(\mathrm{~m}), 604$ (m), $560(\mathrm{~m}), 522(\mathrm{~m}), 507(\mathrm{w})$.
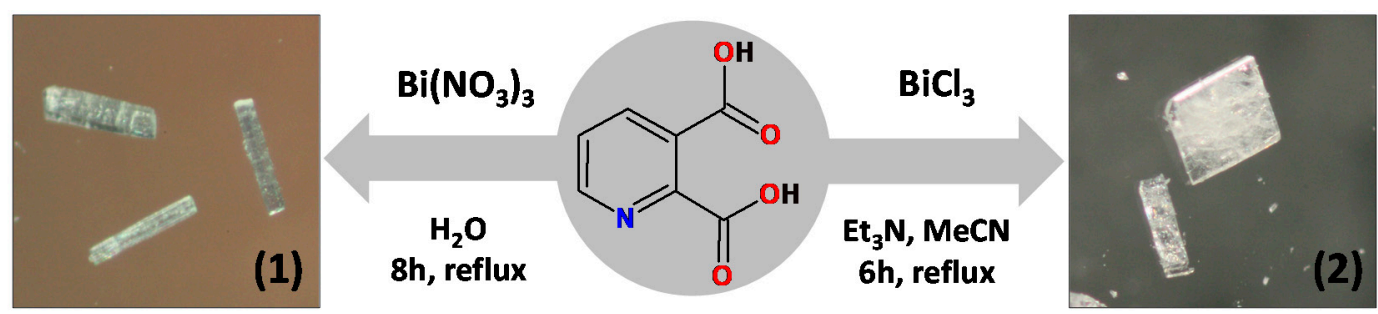

Scheme 2. General reaction conditions employed in the synthesis of $\mathrm{Bi}(\mathrm{III})$ coordination polymers (1 and 2).

\subsection{Synthesis of $\left\{\left(E t_{3} \mathrm{NH}\right)_{2}\left[\mathrm{Bi}(2,3 p y d c)(2,3 p y d c H) \mathrm{Cl}_{2}\right]\right\}_{n}(\mathbf{2})$}

An acetonitrile solution $(10 \mathrm{~mL})$ of triethylamine $(0.75 \mathrm{mmol}, 0.0759 \mathrm{~g})$ was added to $40 \mathrm{~mL}$ of acetonitrile solution of pyridine-2,3-dicarboxylic acid $(0.75 \mathrm{mmol}, 0.1253 \mathrm{~g})$. To the boiling solution was added solid bismuth(III) chloride $(0.25 \mathrm{mmol}, 0.0788 \mathrm{~g})$. The obtained mixture was heated for next $6 \mathrm{~h}$ under a reflux. The resulting mixture was filtered off and left at room temperature to evaporate slowly. After a week, colourless crystals were collected by filtration and dried under vacuum $(\mathrm{m}=0.04479 \mathrm{~g}(0.0549 \mathrm{mmol})$, yield: $22 \%$, based on Bi(III) salt) (Scheme 2). Elemental analysis calculated for $\mathrm{C}_{26} \mathrm{H}_{39} \mathrm{~N}_{4} \mathrm{O}_{8} \mathrm{Cl}_{2} \mathrm{Bi}\left(\mathrm{M}_{\mathrm{r}}=815.49\right)(\%)$ : C 38.29, $\mathrm{H} 4.82, \mathrm{~N}$ 6.87; found: $\mathrm{C} 38.14, \mathrm{H} 4.65$, N 6.78; FT-IR ( $\left.\mathrm{cm}^{-1}\right)$ : $2984(\mathrm{w}), 2712(\mathrm{w}), 2511$ (b), 17708 (m), 1651 (w), 1618 (s), 1573 (s), 1563 (s), $1479(\mathrm{w}), 1445(\mathrm{w}), 1441(\mathrm{~m}), 1395(\mathrm{~m}), 1381(\mathrm{~m}), 1370(\mathrm{~s}), 1350(\mathrm{w}), 1272(\mathrm{~s}), 1221(\mathrm{w}), 1140(\mathrm{~m}), 1094(\mathrm{~m})$, $1063(\mathrm{w}), 1015(\mathrm{w}), 873(\mathrm{~m}), 834(\mathrm{~m}), 800(\mathrm{~m}), 782(\mathrm{w}), 749(\mathrm{~m}), 694(\mathrm{w}), 660(\mathrm{~m}), 611(\mathrm{w}), 557(\mathrm{w}), 540(\mathrm{w})$, $517(\mathrm{w})$.

\subsection{Crystal Data Collection and Refinement}

Diffraction data were collected on an IPDS 2T dual-beam diffractometer (STOE \& Cie GmbH, Darmstadt, Germany) at 120.0(2) K with Mo K $\alpha$ radiation of the microfocus X-ray source (GeniX 3D Mo High Flux, Xenocs, 50 kV, $1.0 \mathrm{~mA}, \lambda=0.71069 \AA$ ). The crystal was thermostated in a nitrogen stream at $120 \mathrm{~K}$ using the CryoStream-800 device (Oxford CryoSystem, Long Hanborough, UK) during the 
entire experiment. Data collection and data reduction were controlled by the X-Area 1.75 program (STOE) [82]. Owing to the high absorption coefficients (11.345 and $\left.5.742 \mathrm{~mm}^{-1}\right)$, numerical absorption corrections were applied based on measured crystal faces. The structures of $\mathbf{1}$ and $\mathbf{2}$ were solved with the ShelXT [83] structure solution programs run under Olex2 [84] using Intrinsic Phasing and refined with the ShelXL [85] refinement package. The WinGX [86] program was used to prepare the final version of CIF files. Diamond [87] was used to prepare the figures. All C-H type hydrogen atoms were attached at their geometrically expected positions and refined as riding on heavier atoms with the usual constraints. Positions of the $\mathrm{N}-\mathrm{H}$ and $\mathrm{O}-\mathrm{H}$ hydrogen atoms were calculated geometrically and taken into account with isotropic temperature factors and refined as constrained, using the AFIX 13 (for N-H), AFIX 6 and AFIX 147 (for O-H) instructions. Aromatic ring (N3, C15-C19) together with the carboxylate group $\mathrm{C}(21) \mathrm{O}(11) \mathrm{O}(12) \mathrm{H}(12 \mathrm{a})$ in $\mathbf{1}$ was found disordered in two positions with probabilities of 0.60(2) and 0.40(2). One atom $\mathrm{Cl} 2$ and five ethyl groups in 2 have been modelled as disordered: Cl2 (s.o.f. 0.69(13)/0.31(13)); C19-C20 (s.o.f. 0.71(4)/0.29(4)); C21-C22 (s.o.f. 0.52(8)/0.48(8)); C23-C24 (s.o.f. 0.86(3)/0.14(3)); C25-C26 (s.o.f. 0.51(4)/0.49(4)); C29-C30 (s.o.f. 0.63(5)/0.37(5)). In compounds 1 and 2, residual electron density is somewhat high and localizes near the heavier Bi atom. In our opinion it is an artefact (e.g., due to cut of Fourier series), since no atom can be present at that location. A summary of crystallographic data is shown in Table 6. Crystallographic data for structure of $\mathbf{1}$ and 2 reported in this paper have been deposited with the Cambridge Crystallographic Data Centre as supplementary publications No. CCDC 1911680 and 1911679. Copies of the data can be obtained free of charge on application to CCDC, 12 Union Road, Cambridge CB2 1EZ, UK (Fax: (+44)-1223-336-033; E-mail: deposit@ccdc.cam.ac.uk).

Table 6. Crystal data and structure refinement for $\mathbf{1}$ and $\mathbf{2 .}$

\begin{tabular}{|c|c|c|}
\hline Empirical Formula & $\mathrm{C}_{28} \mathrm{H}_{16} \mathrm{Bi}_{2} \mathrm{~N}_{4} \mathrm{O}_{17}$ & $\mathrm{C}_{26} \mathrm{H}_{39} \mathrm{BiCl}_{2} \mathrm{~N}_{4} \mathrm{O}_{8}$ \\
\hline CCDC number & 1911680 & 1911679 \\
\hline Formula weight $\left(\mathrm{g} \mathrm{mol}^{-1}\right)$ & 1098.41 & 815.49 \\
\hline Temperature (K) & $120(2)$ & $120(2)$ \\
\hline Wavelength $(\AA)$ & 0.71073 & 0.71073 \\
\hline Crystal system, space group & Triclinic, $P-1$ & Monoclinic, $P 2_{1} / c$ \\
\hline Unit cell dimensions & $\begin{array}{c}\mathrm{a}=8.879(2) \AA \alpha=71.29(3)^{\circ} \\
\mathrm{b}=12.643(3) \AA \beta=80.79(3)^{\circ} \\
\mathrm{c}=15.062(3) \AA \gamma=78.58(3)^{\circ}\end{array}$ & $\begin{array}{c}\mathrm{a}=17.1322(10) \AA \alpha=90^{\circ} \\
\mathrm{b}=12.7920(5) \AA \beta=94.461(4)^{\circ} \\
\mathrm{c}=14.6083(7) \AA \gamma=90^{\circ}\end{array}$ \\
\hline Volume $\left(\AA^{3}\right)$ & $1561.2(7)$ & $3191.8(3)$ \\
\hline $\mathrm{Z}$ & 2 & 4 \\
\hline Calculated density $\left(\mathrm{Mg} \mathrm{m}^{-3}\right)$ & 2.337 & 1.697 \\
\hline Absorption coefficient $\left(\mathrm{mm}^{-1}\right)$ & 11.345 & 5.742 \\
\hline$F(000)$ & 1028 & 1616 \\
\hline Crystal size (mm) & $0.15 \times 0.14 \times 0.13$ & $0.17 \times 0.13 \times 0.11$ \\
\hline Theta range for data collection $\left(^{\circ}\right)$ & 2.55 to 29.278 & 3.219 to 29.509 \\
\hline & $-12 \leq \mathrm{h} \leq 12$ & $-20 \leq h \leq 23$ \\
\hline Limiting indices & $-17 \leq \mathrm{k} \leq 17$ & $-16 \leq \mathrm{k} \leq 17$ \\
\hline & $-20 \leq 1 \leq 20$ & $-20 \leq 1 \leq 20$ \\
\hline Reflections collected/unique & $24,229 / 8402\left[R_{\mathrm{int}}=0.0747\right]$ & $19,630 / 8551\left[R_{\mathrm{int}}=0.0520\right]$ \\
\hline Completeness to theta (\%) & 99.9 & 98.8 \\
\hline Refinement method & \multicolumn{2}{|c|}{ Full-matrix least-squares on $F^{2}$} \\
\hline Data/restraints/parameters & $8402 / 0 / 481$ & $8551 / 2 / 377$ \\
\hline Goodness-of-fit on $F^{2}$ & 1.066 & 1.05 \\
\hline Final $\mathrm{R}$ indices $[I>2 \sigma(I)]$ & $R_{1}=0.0718, w R_{2}=0.1867$ & $R_{1}=0.0631, w R_{2}=0.1629$ \\
\hline $\mathrm{R}$ indices (all data) & $R_{1}=0.1077, w R_{2}=0.2158$ & $R_{1}=0.0880, w R_{2}=0.1827$ \\
\hline Largest diff. peak and hole (e $\AA^{-3}$ ) & 3.404 and -4.129 & 2.368 and -2.488 \\
\hline
\end{tabular}




\subsection{Topological Analysis}

Topological analysis of the metal-organic network of coordination polymers obtained was performed with the ToposPro program package [88] and the TTD collection of periodic network topologies following the concept of the simplified underlying net. Such a net was generated by contracting organic ligands to their centroids, maintaining their connectivity via coordination bonds and including secondary bonds. The underlying networks obtained have been topologically analyzed and classified $[89,90]$.

\subsection{DFT Calculations}

Quantum-chemical calculations were performed in the framework of density-functional theory (DFT). Hybrid three-parameter Becke Lee-Yang-Parr functional B3LYP [91] together with Ahlrichs' triple-zeta split-valence basis set was augmented by Coulomb fitting (def2-TZVP) [92] using resolution of the identity approximation [93]. The Stuttgart-Dresden effective core potential (ECP) for 60 core electrons of Bi was used [94]. The ORCA ab initio, DFT and semiempirical SCF-MO package [95] was used for all calculations. Truncated parts of $\left[\mathrm{Bi}_{2}(2,3 p y d c)_{6}(2,3 p y d c H)_{2}\left(\mathrm{H}_{2} \mathrm{O}\right)\right]^{8-}$ (1) and $\left[\mathrm{Bi}(2,3 \mathrm{pydc})_{2}(2,3 \mathrm{pydcH}) \mathrm{Cl}_{2}\right]^{4-}(2)$ were used as models for the DFT calculations. The model of 1 appeared too large for calculations, so the ligands were truncated, keeping the positions of $\mathrm{N}, \mathrm{O}$-donor atoms and some of non-coordinative organic fragments unchanged in comparison to the initial structure. In the final case, the fragment of $\left[\mathrm{Bi}_{2}(\mathrm{AcO})_{4}\left(\mathrm{H}_{2} \mathrm{O}\right)\left(\mathrm{CH}_{2} \mathrm{NCH}_{2} \mathrm{COO}\right)\right.$ $\left.\left(\mathrm{CH}_{3} \mathrm{NC}\left(\mathrm{CH}_{3}\right) \mathrm{COO}\right)_{2}\left(\mathrm{CH}_{3} \mathrm{NCHCOO}\right)\right]$ for 1 was included in the calculations. The positions of hydrogen atoms were optimized, while other atoms retained the same coordinates as determined from single-crystal X-ray analysis (cif files). Molecular orbitals were localized for analysis using Foster-Boys (spatial localization) algorithm [96]. Electron density distributions were visualized with the UCSF Chimera package [97].

\subsection{Solid-State Photoluminescence Measurements}

The solid-state photoluminescence spectra were recorded at room temperature on a spectrofluorophotometer RF-5301 equipped with a $150 \mathrm{~W}$ Xenon lamp and a solid sample holder (Shimadzu, Kioto, Japan). The 3D emission spectra and 2D excitation and emission spectra were collected with a $1.5 \mathrm{~nm}$ slit width for excitation and a $3 \mathrm{~nm}$ slit width for emission monochromators. Photoluminescence data were processed using Panorama (LabCognition GMBH, Cologne, Germany) software. Photoluminescence quantum yield was measured on a FLS980 spectrofluorimeter (Edinburgh Instruments, Livingston, UK), equipped with an integrating sphere, using $\mathrm{BaSO}_{4}$ as a reference.

\subsection{Solubility and Stability Studies}

Solubility studies were performed using $\mathrm{H}_{2} \mathrm{O}, 1 \mathrm{M} \mathrm{HCl}$ and commonly used organic solvents: $\mathrm{MeOH}, \mathrm{EtOH}$, ${ }^{\mathrm{P}} \mathrm{POH}, \mathrm{MeCN}, \mathrm{DMF}, \mathrm{DMSO}, \mathrm{Me}_{2} \mathrm{CO}$, THF and $\mathrm{CH}_{2} \mathrm{Cl}_{2}$. UV-Vis stability measurements were conducted on a V-630 Jasco UV-Vis spectrophotometer (Jasco Corporation, Tokyo, Japan) using $1 \mathrm{~cm}$ cuvettes. Analyzed compounds (ligand 2,3 $\mathrm{pydcH}_{2}$, complexes 1 and 2) were dissolved in DMSO and diluted with $\mathrm{H}_{2} \mathrm{O}$ or $1 \mathrm{M} \mathrm{HCl} 1: 50(v / v)$ to give concentration of $10^{-4} \mathrm{M}$. All the time-dependent $(0 \mathrm{~h}, 24 \mathrm{~h}$ and $48 \mathrm{~h})$ measurements were recorded at room temperature. The UV-Vis spectrum of product of the reaction $\mathrm{BiCl}_{3}$ with $\mathrm{H}_{2} \mathrm{O}$ was measured in $1 \mathrm{M} \mathrm{HCl}$ with an addition of $2 \% v / v$ DMSO at a concentration of $10^{-4} \mathrm{M}$ at room temperature.

\subsection{Bacterial Strains and Culture Conditions}

Two Helicobacter pylori strains, 26695 [98] and N6 [99], were used to determine the Minimum Inhibitory Concentration (MIC) of the synthesized Bi-compounds by agar dilution. H. pylori 26695 and N6 strains were cultured on Columbia Blood Agar Base plates (CBA, CM331, Oxoid, Basingstoke, UK) supplemented with $10 \%(v / v)$ defibrinated horse blood. Liquid cultures were grown with shaking at 
140 rpm in BBL Brucella Broth (BBL, 211088, Beckton Dickinson, Franklin Lakes, NJ, USA) with 10\% foetal calf serum (Biowest S1810). Liquid and solid H. pylori cultures were supplemented with $0.2 \%$ $(v / v)$ mixture of antibiotics containing $0.3 \mathrm{mg} \mathrm{L}^{-1}$ polymyxin $\mathrm{B}, 12.5 \mathrm{mg} \mathrm{L}^{-1}$ vancomycin, $2.5 \mathrm{mg} \mathrm{L}^{-1}$ amphotericin $\mathrm{B}$ and $6.25 \mathrm{mg} \mathrm{L}^{-1}$ trimethoprim [100]. H. pylori were cultivated under microaerobic conditions $\left(5 \% \mathrm{O}_{2}, 10 \% \mathrm{CO}_{2}, 85 \% \mathrm{~N}_{2}\right)$ at $37^{\circ} \mathrm{C}$.

\subsection{Determination of The Minimum Inhibitory Concentration (MIC)}

The MIC values of bismuth(III) complexes (1 and 2), ligand (pyridine-2,3-dicarboxylic acid) and bismuth subsalicylate (BSS, Sigma-Aldrich, Steinheim, Germany) as a reference were determined by the agar dilution technique. All compounds were dissolved in DMSO and mixed with CBA to give the desired concentrations of the tested compounds. In the initial screening, concentrations ranging from 1 to $100 \mu \mathrm{g} \mathrm{mL}^{-1}$ at intervals of $20 \mu \mathrm{g} \mathrm{mL}^{-1}$ were used. In the final analyses, the bismuth compound concentrations were used at intervals of $2.5 \mu \mathrm{g} \mathrm{mL}-1$. H. pylori liquid cultures of $\mathrm{OD}_{600} \sim 0.5-1.5$ (log-phase, $\mathrm{OD}_{600}=1$ corresponds to $\sim 6.5 \times 10^{8} \mathrm{CFU} \mathrm{mL}^{-1}$ ) were diluted in BBL to $\sim 10^{5} \mathrm{CFU} \mathrm{mL}^{-1}$. Aliquots $(100 \mu \mathrm{L})$ of bacterial suspensions were then streaked onto previously prepared CBA plates containing the different concentrations of tested compounds. CBA plates with DMSO at the same concentration as in CBA plates with compounds, or without DMSO, were used as controls of H. pylori growth under experimental conditions. The plates were incubated for 5 days, and then $H$. pylori growth was assessed. The lowest concentration of a compound at which no H. pylori growth was observed was considered as MIC.

\section{Conclusions}

In summary, we synthesized and fully physicochemically characterized two novel bismuth(III) coordination polymers, with pyridine-2,3-dicarboxylic acid $\left(2,3 \mathrm{pydcH}_{2}\right)$ as the prolinker. The molecular structures of the obtained coordination polymers $\left[\mathrm{Bi}_{2}(2,3 p y d c)_{2}(2,3 p y d c H)_{2}\left(\mathrm{H}_{2} \mathrm{O}\right)\right]_{\mathrm{n}}$ (1) and $\left\{\left(\mathrm{Et}_{3} \mathrm{NH}\right)_{2}\left[\mathrm{Bi}(2,3 \text { pydc })(2,3 \text { pydcH }) \mathrm{Cl}_{2}\right]\right\}_{\mathrm{n}}$ (2) indicated that the coordination environments of the metal centers were different, mainly due to the influence of a free electron pair. The crystallographic studies and quantum-chemical calculations pointed to a hemidirected geometry of bismuth centers in $\mathbf{1}$ and a holodirected geometry in 2 . The various coordination modes of bridging carboxylate ligands $\left(\mu_{4}-\kappa^{2} \mathrm{~N}, \mathrm{O}: \mathrm{KO}^{\prime}: \mathrm{\kappa O}^{\prime \prime}: \kappa^{2} \mathrm{O}^{\prime \prime}, \mathrm{O}^{\prime \prime \prime}\right.$ and $\mu_{5}-\kappa^{2} \mathrm{~N}, \mathrm{O}: \kappa \mathrm{O}: \kappa \mathrm{O}^{\prime}: \mathrm{KO}^{\prime \prime}: \kappa^{2} \mathrm{O}^{\prime \prime}, \mathrm{O}^{\prime \prime \prime}$ in 1 and $\mu-\kappa^{2} \mathrm{~N}, \mathrm{O}: \kappa^{2} \mathrm{O}^{\prime \prime}, \mathrm{O}^{\prime \prime \prime}$ in 2$)$ were responsible for the formation of $1 \mathrm{D}$ chains with 4,5C10 and 2C1 topologies. Both coordination polymers exhibited blue-light photoluminescence with emission maxima at $452 \mathrm{~nm}$ and $463 / 471$ nm for 1 and 2, respectively. The photoluminescence quantum yield of compound 2 was $8.36 \%$, which makes it a good candidate for more specific studies of Bi-based fluorescent materials. Additionally, the in vitro tests evaluating the bacteriostatic activity against Helicobacter pylori showed that $\mathrm{Bi}$ (III) coordination polymers had good antibacterial properties. The MIC values of $\mathbf{1}$ and $\mathbf{2}$ towards reference strain 26695 reached values of 13.7 and $36.8 \mu \mathrm{M}$, respectively. It can be concluded that differences in the structures of coordination polymers $\left(\left[\mathrm{Bi}_{2}(2,3 \text { pydc })_{2}(2,3 p y d c H)_{2}\left(\mathrm{H}_{2} \mathrm{O}\right)\right]_{\mathrm{n}}(\mathbf{1})\right.$ and $\left.\left\{\left(\mathrm{Et}_{3} \mathrm{NH}\right)_{2}\left[\mathrm{Bi}(2,3 \text { pydc })(2,3 \text { pydcH }) \mathrm{Cl}_{2}\right]\right\}_{\mathrm{n}}(2)\right)$ influences the antibacterial activity. Additionally, the H. pylori strain N6 was slightly more sensitive to compound $\mathbf{1}(\mathrm{MIC}=11.4 \mu \mathrm{M})$ than strain 26,695. Therefore, more detailed research in this field should be conducted.

Supplementary Materials: Supplementary materials can be found at http:/www.mdpi.com/1422-0067/21/22/ 8696/s1. Table S1. Selected bands of the most important bonds in the FT-IR spectra of pyridine-2,3-dicarboxylic acid and $\mathrm{Bi}(\mathrm{III})$ polymers 1 and $\mathbf{2}\left(\mathrm{cm}^{-1}\right)$. Figure $\mathrm{S} 1$. The UV-Vis spectrum of the product of the reaction of $\mathrm{BiCl}_{3}$ with $\mathrm{H}_{2} \mathrm{O}$ in $1 \mathrm{M} \mathrm{HCl}$ solution.

Author Contributions: Conceptualization, I.Ł., M.K., J.M. and B.B.; methodology, formal analysis, M.K., J.M.; investigation, M.K., J.M., K.K., O.V.K., A.Z.-P., P.S.; writing-original draft preparation M.K., I.Ł., J.M. and B.B.; writing-review and editing, I.Ł., M.K.; visualization, M.K.; supervision, I.Ł., B.B. All authors have read and agreed to the published version of the manuscript. 
Funding: Publication costs were supported by the Nicolaus Copernicus University in Torun (Excellence Initiative-Research University). Financial support from the statutory activity of subsidy from the Polish Ministry of Science and Higher Education for the Institute of Chemistry of the Jan Kochanowski University in Kielce is gratefully acknowledged (SMGR.RN.20.259).

Acknowledgments: We would like to acknowledge the help and support of Bogumiła Kupcewicz during the photoluminescence experiments.

Conflicts of Interest: The authors declare no conflict of interest.

\section{References}

1. Allendorf, M.D.; Bauer, C.A.; Bhakta, R.K.; Houk, R.J.T. Luminescent metal-organic frameworks. Chem. Soc. Rev. 2009, 38, 1330-1352. [CrossRef] [PubMed]

2. Custelcean, R.; Moyer, B.A. Anion separation with metal-organic frameworks. Eur. J. Inorg. Chem. 2007, 2007, 1321-1340. [CrossRef]

3. Dzhardimalieva, G.I.; Uflyand, I.E. Design and synthesis of coordination polymers with chelated units and their application in nanomaterials science. RSC Adv. 2017, 7, 42242-42288. [CrossRef]

4. Furukawa, H.; Cordova, K.E.; O'Keeffe, M.; Yaghi, O.M. The chemistry and applications of metal-organic frameworks. Science 2013, 341, 1230444. [CrossRef] [PubMed]

5. Pettinari, C.; Marchetti, F.; Mosca, N.; Tosi, G.; Drozdov, A. Application of metal—Organic frameworks. Polym. Int. 2017, 66, 731-744. [CrossRef]

6. Zhang, X.; Wang, W.; Hu, Z.; Wang, G.; Uvdal, K. Coordination polymers for energy transfer: Preparations, properties, sensing applications, and perspectives. Coord. Chem. Rev. 2015, 284, 206-235. [CrossRef]

7. Zhang, Y.; Yuan, S.; Day, G.; Wang, X.; Yang, X.; Zhou, H.C. Luminescent sensors based on metal-organic frameworks. Coord. Chem. Rev. 2018, 354, 28-45. [CrossRef]

8. Novio, F.; Simmchen, J.; Vázquez-Mera, N.; Amorín-Ferré, L.; Ruiz-Molina, D. Coordination polymer nanoparticles in medicine. Coord. Chem. Rev. 2013, 257, 2839-2847. [CrossRef]

9. Liu, R.; Yu, T.; Shi, Z.; Wang, Z. The preparation of metal-organic frameworks and their biomedical application. Int. J. Nanomed. 2016, 11, 1187-1200. [CrossRef]

10. Kowalik, M.; Masternak, J.; Kazimierczuk, K.; Khavryuchenko, O.V.; Kupcewicz, B.; Barszcz, B. An unusual four-nuclear $\mathrm{Pb}$ (II)-pyrrole-2-carboxylato polymer: The effect of the lone pair and non-covalent interactions on the supramolecular assembly and fluorescence properties. J. Solid State Chem. 2019, 273, 207-218. [CrossRef]

11. Kowalik, M.; Masternak, J.; Kazimierczuk, K.; Khavryuchenko, O.V.; Kupcewicz, B.; Barszcz, B. Lead(II) coordination polymers with imidazole-4- and pyrazole-3-carboxylate isomeric linkers: Structural diversity and luminescence properties. J. Solid State Chem. 2018, 266, 100-111. [CrossRef]

12. Kowalik, M.; Masternak, J.; Kazimierczuk, K.; Kupcewicz, B.; Khavryuchenko, O.V.; Barszcz, B. A comparison of structural and luminescence properties of lead(II) coordination polymers with isomeric thiophenecarboxylate ligands. Inorg. Chim. Acta 2018, 471, 446-458. [CrossRef]

13. Masternak, J.; Barszcz, B.; Hodorowicz, M.; Khavryuchenko, O.V.; Majka, A. Synthesis and physicochemical characterization of two lead(II) complexes with O-,N-donor ligands. Lone pair functionality and crystal structure. Spectrochim. Acta Part A Mol. Biomol. Spectrosc. 2015, 136, 1998-2007. [CrossRef] [PubMed]

14. Kowalik, M.; Masternak, J.; Kazimierczuk, K.; Kupcewicz, B.; Khavryuchenko, O.; Barszcz, B. Exploring thiophene-2-acetate and thiophene-3-acetate binding modes towards the molecular, supramolecular structures and photoluminescence properties of $\mathrm{Pb}$ (II) polymers. CrystEngComm 2020, 22, 7025-7035. [CrossRef]

15. Leng, M.; Yang, Y.; Zeng, K.; Chen, Z.; Tan, Z.; Li, S.; Li, J.; Xu, B.; Li, D.; Hautzinger, M.P.; et al. All-inorganic bismuth-based perovskite quantum dots with bright blue photoluminescence and excellent stability. Adv. Funct. Mater. 2017, 28, 1704446. [CrossRef]

16. Dang, P.; Liu, D.; Li, G.; Al Kheraif, A.A.; Lin, J. Recent Advances in Bismuth Ion-Doped Phosphor Materials: Structure Design, Tunable Photoluminescence Properties, and Application in White LEDs. Adv. Opt. Mater. 2020, 8, 1901993. [CrossRef]

17. Zhou, D.D.; Liu, B.M.; Zhou, Y.; Chen, M.Z.; Fang, Y.Z.; Hou, J.S.; Li, L.N.; Sun, H.T. Air-stable and highly luminescent bismuth complex nanoparticles. J. Mater. Chem. C 2016, 4, 4899-4904. [CrossRef] 
18. Bothwell, J.M.; Krabbe, S.W.; Mohan, R.S. Applications of bismuth(III) compounds in organic synthesis. Chem. Soc. Rev. 2011, 40, 4649-4707. [CrossRef]

19. Keogan, D.M.; Griffith, D.M. Current and potential applications of bismuth-based drugs. Molecules 2014, 19, 15258-15297. [CrossRef]

20. Yang, Y.; Ouyang, R.; Xu, L.; Guo, N.; Li, W.; Feng, K.; Ouyang, L.; Yang, Z.; Zhou, S.; Miao, Y. Review: Bismuth complexes: Synthesis and applications in biomedicine. J. Coord. Chem. 2015, 68, 379-397. [CrossRef]

21. Salvador, J.A.; Figueiredo, S.A.; Pinto, R.M.; Silvestre, S.M. Bismuth compounds in medicinal chemistry. Future Med. Chem. 2012, 4, 1495-1523. [CrossRef] [PubMed]

22. Li, H.-M.; Yang, J.-C. Bismuth-Containing Therapy for Helicobacter pylori Eradication. Int. J. Clin. Pharmacol. Pharmacother. 2016, 1, 1-5. [CrossRef] [PubMed]

23. Cordero, B.; Gómez, V.; Platero-Prats, A.E.; Revés, M.; Echeverría, J.; Cremades, E.; Barragán, F.; Alvarez, S. Covalent radii revisited. J. Chem. Soc. Dalton Trans. 2008, 2832-2838. [CrossRef] [PubMed]

24. Shimoni-Livny, L.; Glusker, J.P.; Bock, C.W. Lone Pair Functionality in Divalent Lead Compounds. Inorg. Chem. 1998, 37, 1853-1867. [CrossRef]

25. Hu, M.L.; Morsali, A.; Aboutorabi, L. Lead(II) carboxylate supramolecular compounds: Coordination modes, structures and nano-structures aspects. Coord. Chem. Rev. 2011, 255, 2821-2859. [CrossRef]

26. Tabatabaee, M.; Amjad, S.; Tabatabaei, S.; Molčanov, K. A Bismuth(III) Coordination Polymer with Pyridine-2,3-dicarboxylic Acid as Precursor for Preparation of $\mathrm{Bi}_{2} \mathrm{O}_{3}$ Nanoparticles via Thermal Decomposition. Synth. React. Inorg. Met. Nano Metal Chem. 2014, 44, 507-513. [CrossRef]

27. Wibowo, A.C.; Vaughn, S.A.; Smith, M.D.; Zur Loye, H.C. Novel bismuth and lead coordination polymers synthesized with pyridine-2,5-dicarboxylates: Two single component "white" light emitting phosphors. Inorg. Chem. 2010, 49, 11001-11008. [CrossRef]

28. Wibowo, A.C.; Smith, M.D.; Zur Loye,H.C. A new Kagomé lattice coordination polymer based on bismuth and pyridine-2,5-dicarboxylate: Structure and photoluminescent properties. Chem. Commun. 2011, 47, 7371-7373. [CrossRef]

29. Wibowo, A.C.; Smith, M.D.; Yeon, J.; Halasyamani, P.S.; Zur Loye, H.C. Novel 3D bismuth-based coordination polymers: Synthesis, structure, and second harmonic generation properties. J. Solid State Chem. 2012, 195, 94-100. [CrossRef]

30. Tröbs, L.; Wilke, M.; Szczerba, W.; Reinholz, U.; Emmerling, F. Mechanochemical synthesis and characterisation of two new bismuth metal organic frameworks. CrystEngComm 2014, 16, 5560-5565. [CrossRef]

31. Wibowo, A.C.; Smith, M.D.; zur Loye, H.-C. Structural Diversity of Metal-Organic Materials Containing Bismuth(III) and Pyridine-2,5-Dicarboxylate. Cryst. Growth Des. 2011, 11, 4449-4457. [CrossRef]

32. Thirumurugan, A.; Li, W.; Cheetham, A.K. Bismuth 2,6-pyridinedicarboxylates: Assembly of molecular units into coordination polymers, $\mathrm{CO}_{2}$ sorption and photoluminescence. Dalton Trans. 2012, 41, 4126-4134. [CrossRef] [PubMed]

33. Sheshmani, S.; Kheirollahi, P.D.; Aghabozorg, H.; Shokrollahi, A.; Kickelbick, G.; Shamsipur, M.; Ramezanipour, F.; Moghimi, A. Synthesis and crystal structure of $\mathrm{Ce}^{\mathrm{III}}$ and $\mathrm{Bi}^{\mathrm{III}}$ complexes and solution studies of $\mathrm{Zn}^{\mathrm{II}}, \mathrm{Cd}^{\mathrm{II}}, \mathrm{Pb}^{\mathrm{II}}, \mathrm{Ce}^{\mathrm{III}}$, and $\mathrm{Bi}^{\mathrm{III}}$ complexes obtained from proton transfer compounds containing 2,6-pyridinedicarboxylate ion. Z. Anorg. Allg. Chem. 2005, 631, 3058-3065. [CrossRef]

34. Anjaneyulu, O.; Swamy, K.C.K. Studies on bismuth carboxylates-synthesis and characterization of a new structural form of bismuth(III) dipicolinate. J. Chem. Sci. 2011, 123, 131-137. [CrossRef]

35. Anjaneyulu, O.; Prasad, T.K.; Swamy, K.C.K. Coordinatively polymeric and monomeric bismuth(III) complexes with pyridine carboxylic acids. Dalton Trans. 2010, 39, 1935-1940. [CrossRef]

36. Aghabozorg, H.; Nemati, A.; Derikvand, Z.; Ghadermazi, M. Poly[piperazinediium [[aquabismuthate(III)]-di- $\mu$-pyridine-2,6-dicarboxylato-bismuthate(III)-di- $\mu$-pyridine-2,6-dicarboxylato] monohydrate]. Acta Cryst. E 2008, 64, m374. [CrossRef]

37. Sushrutha, S.R.; Natarajan, S. Bismuth carboxylates with brucite- and fluorite-related structures: Synthesis structure and properties. Cryst. Growth Des. 2013, 13, 1743-1751. [CrossRef]

38. Kan, L.; Li, J.; Luo, X.; Li, G.; Liu, Y. Three novel bismuth-based coordination polymers: Synthesis, structure and luminescent properties. Inorg. Chem. Commun. 2017, 85, 70-73. [CrossRef]

39. Li, H.; Sun, H. Recent advances in bioinorganic chemistry of bismuth. Curr. Opin. Chem. Biol. 2012, 16, 74-83. [CrossRef] 
40. Yang, N.; Sun, H. Biocoordination chemistry of bismuth: Recent advances. Coord. Chem. Rev. 2007, 251, 2354-2366. [CrossRef]

41. Ergül, B.; Koçak, E.; Taş, A.; Filik, L.; Köklü, S. Bismuth, moxifloxacin, tetracycline, lansoprazole quadruple first line therapy for eradication of H. pylori: A prospective study. Clin. Res. Hepatol. Gastroenterol. 2013, 37, 527-529. [CrossRef] [PubMed]

42. Kowalik, M.; Masternak, J.; Barszcz, B. Recent Research Trends on Bismuth Compounds in Cancer Chemoand Radiotherapy. Curr. Med. Chem. 2019, 26, 729-759. [CrossRef] [PubMed]

43. Turner, D.R.; Batten, S.R. Catena-Poly[[copper(II)-bis( $\mu_{3}$-carboxypyridine-2-carboxylato)- $\left.\kappa^{3} \mathrm{~N}, \mathrm{O}^{2}: \mathrm{O}^{3} ; \mathrm{O}^{3}: \mathrm{N}, \mathrm{O}^{2}\right]$ methanol disolvate]. Acta Cryst. E 2007, 63, m452-m454. [CrossRef]

44. Soldin, Ž.; Kukovec, B.M.; Matković-Čalogović, D.; Popović, Z. A Design of Mercury(II) Coordination Polymers with Pyridinedicarboxylic Acids: Structural, Spectroscopic and Thermal Studies. J. Inorg. Organomet. Polym. Mater. 2018, 28, 2080-2089. [CrossRef]

45. Du, Z.X.; Li, J.X. Catena-Poly[[[diaquamanganese(II)]- $\mu_{3}-$ pyridine-2,3-dicarboxylato- $\left.\mathrm{K}^{4} \mathrm{~N}, \mathrm{O}^{2}: \mathrm{O}^{3}: \mathrm{O}^{3^{\prime}}\right]$ dihydrate]. Acta Cryst. E 2008, 64, m1295-m1296. [CrossRef]

46. Jaber, F.; Charbonnier, F.; Faure, R. Preparation and crystal structure of tetraaqua-bis(hydrogenopyridine-2,3(dicarboxylate)bis(pyridine-2,3-dicarboxylate) hexa silver(I) $\left[\mathrm{Ag}_{6}\left(\mathrm{C}_{7} \mathrm{H}_{4} \mathrm{NO}_{4}\right)_{2}\left(\mathrm{C}_{7} \mathrm{H}_{3} \mathrm{NO}_{4}\right)_{2}\left(\mathrm{H}_{2} \mathrm{O}\right)_{4}\right]_{n}$. Polhedron 1996, 15, 2909-2913. [CrossRef]

47. Barszcz, B.; Masternak, J.; Surga, W. Thermal properties of $\mathrm{Ca}(\mathrm{II})$ and $\mathrm{Cd}(\mathrm{II})$ complexes of pyridinedicarboxylates: Correlation with crystal structures. J. Therm. Anal. Calorim. 2010, 101, 633-639. [CrossRef]

48. Barszcz, B.; Hodorowicz, M.; Jabłońska-Wawrzycka, A.; Masternak, J.; Nitek, W.; Stadnicka, K. Comparative study on $\mathrm{Cd}(\mathrm{II})$ and $\mathrm{Ca}(\mathrm{II})$ model complexes with pyridine-2,3-dicarboxylic acid: Synthesis, crystal structure and spectroscopic investigation. Polyhedron 2010, 29, 1191-1200. [CrossRef]

49. Li, M.; Xiang, J.; Yuan, L.; Wu, S.; Chen, S.; Sun, J. Syntheses, Structures, and Photoluminescence of Three Novel Coordination Polymers Constructed from Dimeric $\mathrm{d}^{10}$ Metal Units. Cryst. Growth Des. 2006, 6, 2036-2040. [CrossRef]

50. Yin, W.X.; Liu, Y.T.; Ding, Y.J.; Lin, Q.; Lin, X.M.; Wu, C.L.; Yao, X.D.; Cai, Y.P. Construction of variable dimensional cadmium(II) coordination polymers from pyridine-2,3-dicarboxylic acid. CrystEngComm 2015, 17, 3619-3626. [CrossRef]

51. Patrick, B.O.; Stevens, C.L.; Storr, A.; Thompson, R.C. Structural and magnetic properties of three copper(II) pyridine-2,3-dicarboxylate coordination polymers incorporating the same chain motif. Polyhedron 2003, 22, 3025-3035. [CrossRef]

52. Lush, S.F.; Shen, F.M. Poly[( $\mu_{4}$-pyridine-2,3-dicarboxylato)lead(II)]. Acta Cryst. E 2011, 67, m163-m164. [CrossRef] [PubMed]

53. Li, L.J.; Li, Y. Hydrothermal synthesis and crystal structure of a novel 2-D coordination polymer $\left[\mathrm{Mn}_{2}(\mathrm{pdc})_{2}\left(\mathrm{H}_{2} \mathrm{O}\right)_{3}\right]_{\mathrm{n}} \cdot 2 \mathrm{nH}_{2} \mathrm{O}$ (pdc=pyridine-2,3-dicarboxylate). J. Mol. Struct. 2004, 694, 199-203. [CrossRef]

54. Kang, Y.; Zhang, J.; Li, Z.J.; Cheng, J.K.; Yao, Y.G. Syntheses, structures, and photoluminescent properties of four $\mathrm{d}^{10}$ metal-quinolinato coordination polymers with similar rod-like SBUs. Inorg. Chim. Acta 2006, 359, 2201-2209. [CrossRef]

55. Jablońska-Wawrzycka, A.; Zienkiewicz, M.; Hodorowicz, M.; Rogala, P.; Barszcz, B. Thermal behavior of manganese(II) complexes with pyridine-2,3-dicarboxylic acid: Spectroscopic, X-ray, and magnetic studies. J. Therm. Anal. Calorim. 2012, 110, 1367-1376. [CrossRef]

56. Mantina, M.; Chamberlin, A.C.; Valero, R.; Cramer, C.J.; Truhlar, D.G. Consistent van der Waals radii for the whole main group. J. Phys. Chem. A 2009, 113, 5806-5812. [CrossRef]

57. Harrowfield, J.M.; Lugan, N.; Marandi, F.; Shahverdizadeh, G.H.; Soudi, A.A. Lead(II) complexes of pyridinedicarboxylates-Lattice interactions and metal ion stereochemistry. Aust. J. Chem. 2006, 59, 400-406. [CrossRef]

58. Malone, J.F.; Murray, C.M.; Charlton, M.H.; Docherty, R.; Lavery, A.J. X-H $\cdots \pi$ (phenyl) interactions: Theoretical and crystallographic observations. J. Chem. Soc. Faraday Trans. 1997, 93, 3429-3436. [CrossRef]

59. Takusagawa, F.; Koetzle, T.F. A refinement of the crystal structure of quinolinic acid at $100 \mathrm{~K}$ with neutron diffraction data. Acta Cryst. B 1978, 34, 1149-11154. [CrossRef] 
60. Kvick, Å.; Koetzle, T.F.; Thomas, R.; Takusagawa, F. Hydrogen bond studies. 85. A very short, asymmetrical, intramolecular hydrogen bond: A neutron diffraction study of pyridine-2,3-dicarboxylic acid $\left(\mathrm{C}_{7} \mathrm{H}_{5} \mathrm{NO}_{4}\right)$. J. Chem. Phys. 1974, 60, 3866-3874. [CrossRef]

61. Deacon, G.B.; Phillips, R.J. Relationships between the carbon-oxygen stretching frequencies of carboxylato complexes and the type of carboxylate coordination. Coord. Chem. Rev. 1980, 33, 227-250. [CrossRef]

62. Feng, Y.Q.; Zhong, Z.G.; Wang, H.W.; Xing, Z.Z.; Wang, L. Crystal structure and luminescence properties of a new dinuclear bismuth(III) coordination polymer containing three types of ligands. Zeitschrift für Naturforschung B 2018, 73, 155-160. [CrossRef]

63. Jia, Y.; Li, H.; Guo, Q.; Zhao, B.; Zhao, Y.; Hou, H.; Fan, Y. Template-induced structural isomerism of pyridine-2,3-dicarboxylate and $\mathrm{Pb}^{\Pi}$ with similar high stability and different fluorescent properties. Eur. J. Inorg. Chem. 2012, 2012, 3047-3053. [CrossRef]

64. Wang, E.R.; Huang, J.H.; Gu, X.Y.; Cheng, J.W. Structural modulation of two luminescent bismuth-organic frameworks by the mixed-ligand synthetic strategy. Chin. J. Struct. Chem. 2017, 36, 1100-1107.

65. Feng, Y.Q.; Chen, S.Y.; Wang, L.; Xing, Z.Z. Ionothermal synthesis, structure and luminescent properties of a new 2-D bismuth(III) coordination polymer with (6,5)-connected topological sheet. Chin. J. Struct. Chem. 2018, 37, 1656-1662.

66. Lambert, J.R.; Midolo, P. The actions of bismuth in the treatment of Helicobacter pylori infection. Aliment. Pharmacol. Ther. 1997, 11, 27-33. [CrossRef]

67. Pathak, A.; Blair, V.L.; Ferrero, R.L.; Kedzierski, L.; Andrews, P.C. Structural influences on the activity of bismuth(III) indole-carboxylato complexes towards Helicobacter pylori and Leishmania. J. Inorg. Biochem. 2017, 177, 266-275. [CrossRef]

68. Andrews, P.C.; Ferrero, R.L.; Junk, P.C.; Kumar, I.; Luu, Q.; Nguyen, K.; Taylor, J.W. Bismuth(III) complexes derived from non-steroidal anti-inflammatory drugs and their activity against Helicobacter pylori. Dalton Trans. 2010, 39, 2861-2868. [CrossRef]

69. Schlesinger, M.; Pathak, A.; Richter, S.; Sattler, D.; Seifert, A.; Rüffer, T.; Andrews, P.C.; Schalley, C.A.; Lang, H.; Mehring, M. Salicylate-functionalized bismuth oxido clusters: Hydrolysis processes and microbiological activity. Eur. J. Inorg. Chem. 2014, 2014, 4218-4227. [CrossRef]

70. Andrews, P.C.; Blair, V.L.; Ferrero, R.L.; Junkb, P.C.; Kumar, I. Making Bispirin: Synthesis, structure and activity against Helicobacter pylori of bismuth(III) acetylsalicylate. Chem. Commun. 2013, 49, 2870-2872. [CrossRef]

71. Andrews, P.C.; Deacon, G.B.; Ferrero, R.L.; Junk, P.C.; Karrar, A.; Kumar, I.; MacLellan, J.G. Bismuth(III) 5-sulfosalicylate complexes: Structure, solubility and activity against Helicobacter pylori. Dalton Trans. 2009, 6377-6384. [CrossRef] [PubMed]

72. Andrews, P.C.; Busse, M.; Deacon, G.B.; Ferrero, R.L.; Junk, P.C.; MacLellan, J.G.; Vom, A. Remarkable in vitro bactericidal activity of bismuth(III) sulfonates against Helicobacter pylori. Dalton Trans. 2012, 41, 11798-11806. [CrossRef] [PubMed]

73. Busse, M.; Trinh, I.; Junk, P.C.; Ferrero, R.L.; Andrews, P.C. Synthesis and characterisation of bismuth(III) aminoarenesulfonate complexes and their powerful bactericidal activity against Helicobacter pylori. Chem. Eur. J. 2013, 19, 5264-5275. [CrossRef] [PubMed]

74. Andrews, P.C.; Busse, M.; Deacon, G.B.; Ferrero, R.L.; Junk, P.C.; Huynh, K.K.; Kumar, I.; MacLellan, J.G. Structural and solution studies of phenylbismuth(III) sulfonate complexes and their activity against Helicobacter pylori. Dalton Trans. 2010, 39, 9633-9641. [CrossRef]

75. Andrews, P.C.; Ferrero, R.L.; Forsyth, C.M.; Junk, P.C.; MacLellan, J.G.; Peiris, R.M. Bismuth(III) saccharinate and thiosaccharinate complexes and the effect of ligand substitution on their activity against Helicobacter pylori. Organometallics 2011, 30, 6283-6291. [CrossRef]

76. Andrews, P.C.; Ferrero, R.L.; Junk, P.C.; Peiris, R.M. A sweeter way to combat Helicobacter pylori? Bismuth(III) complexes and oxido-clusters derived from non-nutritive sweeteners and their activity against $H$. pylori. J. Organomet. Chem. 2013, 724, 88-94. [CrossRef]

77. Pathak, A.; Blair, V.L.; Ferrero, R.L.; Mehring, M.; Andrews, P.C. Bismuth(III) benzohydroxamates: Powerful anti-bacterial activity against Helicobacter pylori and hydrolysis to a unique $\mathrm{Bi}_{34}$ oxido-cluster $\left[\mathrm{Bi}_{34} \mathrm{O}_{22}(\mathrm{BHA})_{22}(\mathrm{H}-\mathrm{BHA})_{14}(\mathrm{DMSO})_{6}\right]$. Chem. Commun. 2014, 50, 15232-15234. [CrossRef] 
78. Pathak, A.; Blair, V.L.; Ferrero, R.L.; Junk, P.C.; Tabor, R.F.; Andrews, P.C. Synthesis and structural characterisation of bismuth(III) hydroxamates and their activity against Helicobacter pylori. Dalton Trans. 2015, 44, 16903-16913. [CrossRef]

79. Song, Z.; Zhou, L.; Zhang, J.; He, L.; Bai, P.; Xue, Y. Levofloxacin, bismuth, amoxicillin and esomeprazole as second-line Helicobacter pylori therapy after failure of non-bismuth quadruple therapy. Dig. Liver Dis. 2016, 48, 506-511. [CrossRef]

80. Gokcan, H.; Oztas, E.; Koral Onal, I. Different bismuth-based therapies for eradicating Helicobacter pylori: Randomized clinical trial of efficacy and safety. Clin. Res. Hepatol. Gastroenterol. 2016, 40, 124-131. [CrossRef]

81. Muller, N.; Amiot, A.; Le Thuaut, A.; Bastuji-Garin, S.; Deforges, L.; Delchier, J.C. Rescue therapy with bismuth-containing quadruple therapy in patients infected with metronidazole-resistant Helicobacter pylori strains. Clin. Res. Hepatol. Gastroenterol. 2016, 40, 517-524. [CrossRef] [PubMed]

82. STOE \& Cie GmbH. X-area 1.75, Software Package for Collecting Single-Crystal Data on STOE Area-Detector Diffractometers, for Image Processing, Scaling Reflection Intensities and for Outlier Rejection; STOE \& Cie GmbH: Darmstadt, Germany, 2015; Available online: https://www.stoe.com/wp-content/uploads/2014/03/STO012_ Prospekt_X-Area_web.pdf (accessed on 15 October 2020).

83. Sheldrick, G.M. SHELXT-Integrated space-group and crystal-structure determination. Acta Cryst. A 2015, 71, 3-8. [CrossRef] [PubMed]

84. Dolomanov, O.V.; Bourhis, L.J.; Gildea, R.J.; Howard, J.A.K.; Puschmann, H. OLEX2: A complete structure solution, refinement and analysis program. J. Appl. Cryst. 2009, 42, 339-341. [CrossRef]

85. Sheldrick, G.M. Crystal structure refinement with SHELXL. Acta Cryst. C 2015, 71, 3-8. [CrossRef] [PubMed]

86. Farrugia, L.J. WinGX and ORTEP for Windows: An update. J. Appl. Cryst. 2012, 45, 849-854. [CrossRef]

87. Brandenburg, K.; Putz, H. Diamond-Crystal and Molecular Structure Visualisation Crystal Impact; 3.1f; Rathausgasse 30; GbR: Bonn, Germany, 1997.

88. Blatov, V.A.; Shevchenko, A.P.; Proserpio, D.M. Applied Topological Analysis of Crystal Structures with the Program Package ToposPro. Cryst. Growth Des. 2014, 14, 3576-3586. [CrossRef]

89. O'Keeffe, M.; Yaghi, O.M. Deconstructing the crystal structures of metal-organic frameworks and related materials into their underlying nets. Chem. Rev. 2012, 112, 675-702. [CrossRef]

90. Li, M.; Li, D.; O'Keeffe, M.; Yaghi, O.M. Topological analysis of metal-organic frameworks with polytopic linkers and/or multiple building units and the minimal transitivity principle. Chem. Rev. 2014, 114, 1343-1370. [CrossRef]

91. Becke, A.D. Density-functional thermochemistry. III. The role of exact exchange. J. Chem. Phys. 1993, 98, 5648-5652. [CrossRef]

92. Weigend, F.; Ahlrichs, R. Balanced basis sets of split valence, triple zeta valence and quadruple zeta valence quality for $\mathrm{H}$ to Rn: Design and assessment of accuracy. Phys. Chem. Chem. Phys. 2005, 7, 3297-3305. [CrossRef]

93. Neese, F.; Wennmohs, F.; Hansen, A.; Becker, U. Efficient, approximate and parallel Hartree-Fock and hybrid DFT calculations. A “chain-of-spheres" algorithm for the Hartree-Fock exchange. Chem. Phys. 2009, 356, 98-109. [CrossRef]

94. Metz, B.; Stoll, H.; Dolg, M. Small-core multiconfiguration-Dirac-Hartree-Fock-adjusted pseudopotentials for post-d main group elements: Application to $\mathrm{PbH}$ and PbO. J. Chem. Phys. 2000, 113, 2563-2569. [CrossRef]

95. Neese, F. The ORCA program system. WIREs Comput. Mol. Sci. 2012, 2, 73-78. [CrossRef]

96. Kleier, D.A.; Halgren, T.A.; Hall, J.H.; Lipscomb, W.N. Localized molecular orbitals for polyatomic molecules. I. a comparison of the Edmiston-Ruedenberg and Boys localization methods. J. Chem. Phys. 1974, 61, 3905-3919. [CrossRef]

97. Pettersen, E.F.; Goddard, T.D.; Huang, C.C.; Couch, G.S.; Greenblatt, D.M.; Meng, E.C.; Ferrin, T.E. UCSF Chimera-A visualization system for exploratory research and analysis. J. Comput. Chem. 2004, 25, 1605-1612. [CrossRef]

98. Tomb, J.F.; White, O.; Kerlavage, A.R.; Clayton, R.A.; Sutton, G.G.; Fleischmann, R.D.; Ketchum, K.A.; Klenk, H.P.; Gill, S.; Dougherty, B.A.; et al. The complete genome sequence of the gastric pathogen Helicobacter pylori. Nature 1997, 388, 539-547. [CrossRef] [PubMed] 
99. Behrens, W.; Bönig, T.; Suerbaum, S.; Josenhans, C. Genome sequence of Helicobacter pylori hpEurope strain N6. J. Bacteriol. 2012, 194, 3725-3726. [CrossRef]

100. Contreras, M.; Thiberge, J.M.; Mandrand-Berthelot, M.A.; Labigne, A. Characterization of the roles of NikR, a nickel-responsive pleiotropic autoregulator of Helicobacter pylori. Mol. Microbiol. 2003, 49, 947-963. [CrossRef]

Publisher's Note: MDPI stays neutral with regard to jurisdictional claims in published maps and institutional affiliations.

(C) 2020 by the authors. Licensee MDPI, Basel, Switzerland. This article is an open access article distributed under the terms and conditions of the Creative Commons Attribution (CC BY) license (http://creativecommons.org/licenses/by/4.0/). 